\title{
LA VIOLENCIA DOMÉSTICA EN LA LEGISLACIÓN ESPAÑOLA: ESPECIAL REFERENCIA AL DELITO DE MALTRATO HABITUAL (ART. 173.2 DEL CÓDIGO PENAL)
}

I. Consideraciones previas; II. Evolución de la regulación legislativa del delito de violencia doméstica habitual; III. El bien jurídico protegido en el artículo 173. 2 del Código penal: 1. La integridad moral como bien jurídico protegido del art. 173 del Código penal; 2. La integridad moral como bien jurídico protegido del delito de violencia doméstica habitual; IV. La conducta típica del delito de violencia doméstica habitual: 1. La conducta típica del número 2 del art. 173 del Código penal; 2. La conducta típica del número 1 del art. 173 del Código penal; 3. La ¿ diferencia? entre las conductas de los números $1^{\circ}$ y $2^{\circ}$ del art. 173 del Código penal: $V$. ¿Resulta justificada una regulación autónoma del delito de violencia doméstica habitual en el art. 173.2 del Código penal?

Cuando recibí la invitación a participar en el Homenaje al Profesor Juan Bustos, gran penalista y maestro, me planteé la conveniencia de abordar un tema como el de la Violencia doméstica, ya que no había sido una materia por la que el recordado Profesor manifestara excesiva preocupación. Sin embargo, tanto el planteamiento de la regulación legislativa realizada en España en los últimos tiempos respecto a la denominada Violencia de Género, como mi propia postura al respecto, me convenció de que podía ser una buena forma de rendir homenaje al fallecido maestro. Si hubo algún tema al que dedicó especial atención y esfuerzos el profesor Bustos Ramírez, fue precisamente el de las limitaciones de la intervención del Estado en las esferas de Derechos y libertades de los ciudadanos, donde se posicionó, sin lugar a dudas, a favor de un indiscutible e irrenunciable respeto incondicional a las garantías y principios básicos informadores de un Estado de Derecho. Desde el análisis y determinación de los bienes jurídicos como fundamento irrenunciable para legitimar cualquier intervención estatal en materia penal, abogó por un Derecho penal respetuoso de los principios básicos y tradicionales que se derivan de un Estado social y democrático de Derecho.

La Violencia doméstica, la Violencia intrafamiliar, o la denominación que se le está dando últimamente, de forma incorrecta en mi opinión, de Violencia de Género, supone un problema social cuya solución legislativa va a implicar, como expondré, un ataque frontal a ese Derecho penal garantista que defendía el profesor Bustos Ramírez. En su memoria, en el presente trabajo, intento defender la irrenunciabilidad de los postulados mantenidos por el, desafortunadamente, desaparecido académico.

\footnotetext{
* Profesora Titular de Derecho Penal de la Universidad de Sevilla. España.
} 
Núñez Castaño - La violencia doméstica en la legislación española...

\section{Consideraciones previas}

La denominada violencia de género se ha erigido en una de las principales preocupaciones del legislador español, y fiel prueba de ello ha sido la continua relación de modificaciones legislativas que se han realizado en los últimos años ${ }^{1}$. Independientemente de lo acertado o no de la denominación como "violencia de género", lo cierto es que el legislador con las regulaciones realizadas trataba de dar una mayor protección y castigo a los comportamientos violentos realizados entre un determinado círculo de personas unidas por lazos familiares, de convivencia (actual o no) y/o de dependencia; en definitiva, conductas realizadas en un determinado entorno "familiar" y/o "doméstico".

No resulta ninguna novedad afirmar que nuestra sociedad se mueve por tendencias originadas, generalmente, por los medios de comunicación, y, desde hace algunos años, resulta prácticamente imposible que transcurra un solo día sin que algún caso de violencia en el ámbito familiar trascienda a la opinión pública. Ello nos conciencia de que la violencia en el hogar se ha convertido en un grave problema de la sociedad actual; y ello, no por la novedad que el tema pudiera implicar, sino por el cambio que se está produciendo en el seno de la sociedad. Cambio que se refleja en un doble aspecto: en una mayor protección hacia los miembros más débiles de las estructuras familiares, y en una menor tolerancia de la sociedad hacia los comportamientos vejatorios y violentos contra las mismas.

Sin embargo, por mucho que la alarma social y los medios de comunicación, coloquen el tema de la violencia doméstica en primera plana de la actualidad, no se trata de un fenómeno nuevo. De hecho estas situaciones proceden de épocas ancestrales en que la violencia ha sido utilizada como instrumento de poder y de dominio. La situación actual viene derivada del cambio social, de una mayor toma de conciencia, sobre todo por la mujer, respecto de sus derechos y de su papel, de una mayor sensibilización en la sociedad, que provocan

\footnotetext{
1 Así, por ejemplo, podemos citar la LO 11/1999, de 30 de Abril, de Modificación del Título VIII del Libro II de Código penal; LO 14/1999, de 9 de Junio, de Modificación del Código penal en Materia de Protección a las víctimas de malos tratos y de la Ley de Enjuiciamiento Criminal; LO 11/2003, de 29 de Septiembre, de medidas concretas en materia de seguridad ciudadana, violencia doméstica e integración social de los extranjeros; y por último (¿?)LO 1/2004, de 28 de diciembre, de Medidas de Protección Integral contra la Violencia de Género.

${ }^{2}$ Sobre esta denominación, vid. MARTÍNEZ-BUJÁN PÉREZ, en el Prólogo a Núñez Castaño, El delito de malos tratos en el ámbito familiar, Valencia 2002, pág. 11, nota 1. En realidad, la denominación Violencia de género que se ha impuesto en las legislaciones de nuestro entorno, se deriva del anglicismo Gender Violence, con el que genéricamente se pretendía determinar la Violencia por razón de sexo. Con ello, se están refiriendo a las situaciones y comportamientos violentos que sufren las personas por razón de sexo; es decir, en el caso de las mujeres, por el hecho de ser mujeres. En mi opinión, como expondré más adelante, ni la traducción realizada es la más adecuada en nuestro idioma, ni, y esto es aún más grave, el contenido y la finalidad de las reformas legislativas van encaminadas a otorgar protección y tutela en el caso de violencia contra las mujeres por razón de sexo.
} 
un sentimiento de protección y amparo en las víctimas de estos comportamientos, animándolas a exteriorizar las situaciones con el consiguiente aumento del número de denuncias que ello lleva aparejado.

Esta nueva actitud ante el fenómeno de la violencia en el ámbito familiar y/o doméstico, implicó que las instituciones tanto internacionales como nacionales reaccionaran ante el problema, arbitrando una serie de medidas dirigidas a erradicar este tipo de comportamientos. Estas medidas se dirigen a dos aspectos básicos: a la necesidad de concienciar a la sociedad y a las propias víctimas de estas agresiones, y al empleo de los medios legales, sociales y sanitarios necesarios para acabar con estos comportamientos.

Fiel reflejo de esto, son los sucesivos Planes de Acción contra la Violencia doméstica $^{3}$, aprobados en España, que estructuraban una serie de medidas encaminadas a erradicar estas situaciones. Medidas que se centraban en seis grandes apartados: sensibilización y prevención, educación y formación, recursos sociales, sanidad, legislación y práctica jurídica, e investigación. Hasta la Ley Integral de Medidas de Protección contra la violencia de Género (Ley Orgánica 1/2004, de 28 de Diciembre), la actuación de los poderes públicos se centró, casi exclusivamente, en el apartado legislativo, mediante una reiterada y continua reforma de la legislación penal y procesal, que no dio solución a los casos de violencia doméstica, pero que si supuso una importante intensificación de la intervención penal en este ámbito. Esta avalancha de reformas penales ( $\mathrm{y}$ procesales) no contribuyó, sin embargo, a un descenso de los casos de violencia doméstica, y ello nos hace pensar, como bien señalan BOLDOVA PASAMAR y RUEDA MARTIN ${ }^{4}$ " "que a la vista del incremento incesante de cifras de este tipo de violencia, hace presagiar que no han alcanzado su fin".

Hasta el momento, la (pen)última reforma, realizada por el legislador español, en la materia la constituye la Ley orgánica $1 / 2004$, que trata de aportar una visión integral del problema de la violencia en determinados ámbitos de relaciones, aunque se circunscribe de modo genérico a la protección de la mujer. El ámbito de la Ley abarca aspectos preventivos, educativos, sociales, asistenciales, y de importantes reformas legislativas, esencialmente procesales y penales. Sin embargo, a pesar del innegable avance que pudiera implicar una regulación de este tipo, sobre todo en lo que se refiere al establecimiento de medidas extrajurídicas para hacer frente a este problema, lo cierto es que la controversia surgió desde el primer momento. El principal y más importante reproche radica en la afirmación

\footnotetext{
${ }^{3}$ En 1998 se aprobó el Primer Plan de Acción contra la Violencia Doméstica (1998-2001) por Acuerdo del Consejo de Ministros de 30 de Abril de 1998; en el año 2001 se presenta el II Plan Integral contra la Violencia Doméstica (2001-2004), aprobado por Acuerdo del Consejo de Ministros de 11 de Mayo de 2001.

4 BOLDOVA PASAMAR/RUEDA MARTIN, "Consideraciones político-criminales en torno a los delitos de violencia de género", en La reforma penal en torno a la violencia doméstica y de género, Boldova Pasamar/Rueda martín (coords.), Barcelona, 2006, pág. 14.
} 
Núñez Castaño - La violencia doméstica en la legislación española...

de que presenta graves defectos puesto que se introduce una discriminación positiva de la mujer en el ámbito penal que pudiera resultar inconstitucional por infringir los principios de igualdad y proporcionalidad en relación con la regulación penal de este tipo de situaciones, sobre todo en lo que se refiere al artículo 153 del Código penal. ${ }^{5}$ Un ejemplo de las numerosas críticas y reproches que recibió esta regulación, lo constituye el Informe que emitió el Consejo General del Poder Judicial, el 21 de Junio de 2004, durante la tramitación de la Ley, donde se afirmaba la existencia de un evidente agravio comparativo entre la protección jurídica que se quería otorgar a las mujeres y la que se establecía con respecto de otras posibles víctimas de maltrato que, al encontrarse en situaciones muy similares a las que ellas padecían, deberían recibir la misma protección.

\footnotetext{
${ }^{5}$ Respecto a la controversia ocasionada por la nueva regulación del Art.- 153, vid. MENDOZA CALDERÓN, "Hacia un Derecho penal sin fundamentación material del injusto: la introducción del nuevo art. 153 del Código penal", en Revista General de Derecho Penal, Mayo 2005, n 3, www.iustel.com, págs. 1 y ss., consultado el 19 de Noviembre de 2008; COLMENERO MÉNDEZ DE LUARCA, "La discriminación positiva en el ámbito penal", en La discriminación positiva, Manuales de Formación continuada, Consejo General del Poder Judicial, Madrid 2006, págs. 289307; QUERALT i JIMÉNEZ, "La respuesta penal de la Ley Orgánica 1/2004 a la Violencia de Género", en La Ley integral de medidas de protección contra la violencia de género, Cuadernos de Derecho Judicial, XXII, 2005, págs. 147 a 152; BOLDOVA PASAMAR/RUEDA MARTIN, "La discriminación positiva de la mujer en el ámbito penal", en La Ley, 14-2-2004, pág. 3; CAMPOS CRISTÓBAL, "Tratamiento penal de la violencia de género", en La nueva Ley contra la Violencia de género (LO 1/2004 de 28 de Diciembre), Boix Reig/Martínez García (coords.), Madrid, 2005, págs. 269-270; MIRAT HERNÁNDEZ/ARMENDÁRIZ LEÓN, Violencia de género versus violencia doméstica: Consecuencias jurídico penales. Estudio del Titula IV de la Ley Orgánica 1/2004, de 28 de Diciembre, de medidas de protección integral contra la Violencia de Género, Madrid, 2006, págs. 117 a 126; LAURENZO COPELLO, "Violencia de género y Derecho penal de excepción: entre el discurso de la resistencia y el victimismo punitivo", en Estudios penales en Homenaje a Enrique Gimbernat, García Valdés/Cuerda Riezu/Martínez Escamilla/Alcacer Guirao/Valle Mariscal de Gante (coords.), tomo II, Madrid 2008, págs. 2098 y ss.; la misma, "La violencia de género en la Ley Integral. Valoración político criminal”, en Revista Electrónica de Derecho Penal y Criminología, 2005, pág. 11 y ss., http://criminet.ugr.es/recpc, 07-08 (2005), consultada el 25 de Octubre de 2008; RUBIDO DE LA TORRE, Ley de Violencia de Género. Ajuste de constitucionalidad en materia penal, Valencia 2007, págs. 81 y ss.
} 
Tan intensa fue la polémica a este respecto ${ }^{6}$, que se interpusieron diversas

"De hecho, la Ley de Medidas de Protección Integral contra la Violencia de Género introdujo lo
que se denominó "perspectiva de género", y ello dio lugar a una única y esencial cuestión sobre si
resultaba legítimo establecer una protección reforzada para la mujer en los casos de ataques
violentos por parte de su pareja o expareja masculina. Un sector doctrinal, entendió que resultaba justificable y necesaria esta hiperprotección dado que se trataba de una "acción positiva" respecto de la mujer, encaminada a lograr una situación de igualdad material. Sin embargo, la mayoría de la doctrina penal señaló, de inmediato, que el Derecho penal no era, por su propia naturaleza, un instrumento jurídico adecuado para establecer verdaderas medidas de acción positiva, ni de discriminación positiva a favor de la mujer; el Derecho penal no puede aportar soluciones a la desigualdad estructural ya que el hecho de agravar las penas de los agresores no incide positivamente en el desigual acceso al trabajo o en el reparto de los roles en las estructuras sociales. Estas soluciones tienen que lograrse por otro tipo de política y normativa que nada tienen que ver con el ámbito penal, cfrs. MANJÓN-CABEZA OLMEDA, "Violencia de género: discriminación positiva, perspectiva de género y Derecho penal. Algunas cuestiones sobre la competencia de los nuevos juzgados de violencia sobre la mujer", en Tutela penal y Tutela judicial frente a la violencia de género, Madrid 2006, pág. 48; ALONSO ÁLAMO, "Protección penal de la igualdad y Derecho penal de Género", Cuadernos de Política Criminal, no 95, 2008, pág. 24; MATA Y MARTIN, "Modificaciones jurídico penales de la LO 1/2004, de medidas de protección integral contra la violencia de género", Revista de Derecho y Proceso Penal, no 15, 2006, págs. 43 y ss.

Han sido muchos y variados los intentos realizados por parte de la doctrina penal a fin de justificar esta "perspectiva de género" que introduce la Ley Orgánica 1/2004, desde quienes mantenían que las reformas realizadas venían a imponer un mayor castigo a los ataques que los hombres realizan sobre mujeres por razones o motivos discriminatorios, motivos que determinan la concurrencia de un mayor desvalor de la culpabilidad justificando así una mayor pena, cfrs. BOLDOVA PASAMAR/RUEDA MARTIN, "La discriminación positiva de la mujer en el ámbito penal”, La Ley, no 6146, 2004, págs. 6 a 10; hasta aquellos que fundamentan el mayor castigo en que las agresiones que los hombres realizan contra las mujeres, atentan contra otros bienes jurídicos de la mujer, además de su salud e integridad corporal. Con ello, presentan un mayor desvalor de resultado que justifica su mayor punición, cfrs. RAMÓN RIBAS, Violencia de género y violencia doméstica, Valencia 2008, págs. 115 y 122; QUERALT JIMÉNEZ, aunque afirma el carácter pluriofensivo de estos delitos, sin embargo, fundamenta la cualificación en el mayor desvalor de acción derivado de un abuso de poder, "La última respuesta penal a la violencia de género", La Ley, no 6420, 2006, págs. 5 a 19.

Pero todos estos intentos doctrinales encaminados a legitimar la opción punitiva del legislador español no lograron erradicar las numerosas críticas sobre la misma que llegaron a tildarla de inconstitucional. No se puede hacer radicar el fundamento de una mayor pena en la afirmación de que el hombre resulta, por definición, más peligroso que la mujer, o en que la agresión se realiza con intención de discriminarla y someterla, entre otras cosas porque no responde a la realidad criminológica de este delito, y porque parece fijarse mucho más en las características personales del autor que en las del hecho, con todo lo que ello conlleva, cfrs. GONZÁLEZ CUSSAC, "La intervención penal contra la violencia de género desde la perspectiva del principio de proporcionalidad", en Tutela procesal frente a hecho de violencia de género, Universitat Jaume I, Castellón, 2007, pág. 475. En realidad, afirmar que dichas agresiones eran manifestación necesaria e instrumento para la discriminación de la mujer realizada por el hombre, y que reflejaban el abuso de poder de éste, suponía una presunción contraria a reo que es completamente inadmisible en Derecho penal, cfrs. GONZÁLEZ CUSSAC, ult. op. cit., págs. 426 y ss, y 476 y ss; BOLEA BARDÓN, "En los límites del Derecho penal frente a la violencia doméstica y de género", en Revista Electrónica de Derecho Penal y Criminología, 2007, pág. 5, http://criminet.ugr.es/recpc, 09-02 (2007), consultada el 25 de Octubre de 2008; MANJÓN-CABEZA OLMEDA, "Violencia de 
Núñez Castaño - La violencia doméstica en la legislación española...

cuestiones de inconstitucionalidad sobre la regulación contenida en la ley ${ }^{7}$, recientemente resueltas por el Tribunal Constitucional en diversas Sentencias, la última de las cuales es la número 59/2008, de 14 de mayo, donde afirma la plena constitucionalidad de la regulación legislativa realizada en esta materia por la Ley Orgánica 1/2004. A pesar de las enormes reservas que me causa esta resolución del Tribunal Constitucional, no voy a entrar en el análisis de la misma por cuanto excedería en demasía el objeto de este trabajo ${ }^{8}$.

Baste aquí con señalar, que la Ley Orgánica 1/2004, supone una regulación integral de la violencia contra la mujer en un determinado ámbito, como es el de la relación familiar, doméstica, de convivencia (actual o no) y/o de dependencia. En definitiva, a pesar de denominarse de manera genérica, "Violencia de género", la Ley se circunscribe nuevamente al ámbito de la violencia doméstica o familiar, centrándose, eso sí, en la protección específica de la mujer como sujeto pasivo de este tipo de comportamientos, y en el castigo específico del hombre como sujeto activo de los mismos?

género....", cit., págs. 49 y ss. Es más, se consideraba que tratar de fundamentar parte de la responsabilidad de dicho sujeto activo en un concepto como el de género que alude a la discriminación social de la mujer, supone intentar sustentarla en un situación (la de la discriminación) que no había sido generada por él sino por la sociedad, con lo que siempre vulnerará el principio de culpabilidad, cfrs. GALÁN MUÑOZ, "De la «Violencia doméstica» a la «Violencia de género»: ¿Un paso fallido hacia el Derecho penal del enemigo?”, en Estudios sobre la Tutela penal de la Violencia de Género, Núñez Castaño (directora), Valencia 2009, págs. 69 y 70.

Por todo ello, un importante sector doctrinal consideró que se trataba de una medida legislativa carente de un verdadero fundamento material. Una medida que castigaba más al hombre por el mero hecho de ser hombre y que, por ello, violaba de forma flagrante los principios de presunción de inocencia, culpabilidad, igualdad y proporcionalidad, cfrs, GALÁN MUÑOZ, ibidem; BOLEA BARDÓN, "En los límites del Derecho penal...", cit., pág. 25. En consecuencia, se consideraba esta reforma como un ejemplo más del "recurso abusivo al Derecho penal" y de "populismo punitivo" que desde la base de la idea de seguridad y prevención, llegaba a convertir el Derecho penal en un medio de lucha o guerra contra determinados sujetos (los hombres maltratadores, en este caso) que dejan de ser ciudadanos para pasar a ser tratados como enemigos.

${ }^{7}$ Cuestiones de inconstitucionalidad interpuestas por los Juzgados de lo Penal números 1 (Auto de 3 de Agosto de 2005) y 4 (Auto de 29 de Julio de 2005) de Murcia, y por el Juzgado de lo Penal número 1 de Valladolid (Auto de 15 de Septiembre de 2005).

${ }^{8}$ No soy la única que mantengo importantes reservas tanto acerca de la constitucionalidad de la regulación contenida en el art. 153.1 del Código penal español como de las últimas resoluciones de nuestro Tribunal Constitucional, concretamente la Sentencia 59/2008, de 14 de mayo; precisamente por eso, esta Sentencia tuvo un elevado número de votos particulares, concretamente tres, que expresaban su disconformidad con muchos de los aspectos de la referida sentencia. Para un análisis más detallado y pormenorizado acerca del contenido de la Sentencia y de los Votos particulares, vid. GALÁN MUÑOZ, "De la «Violencia doméstica» a la «Violencia de género»", cit., pags. 71 y ss.; MENDOZA CALDERÓN, "El delito de maltrato ocasional del artículo 153 del Código penal: La influencia del modelo de seguridad ciudadana en el actual Derecho penal", en Estudios sobre la Tutela penal de la Violencia de Género, Núñez Castaño (directora), Valencia 2009, págs. 135 y ss.

${ }^{9}$ Respecto a esta restricción de la regulación legal, vid. LAURENZO COPELLO, "La violencia de género en la Ley integral", cit., págs. 3 y 6, donde afirma que a pesar de que el artículo 1 de la Ley 
En mi opinión, una cosa es la violencia "de género" o violencia "contra la mujer", y otra cosa, totalmente distinta, es la "violencia doméstica". Es evidente la necesidad de una legislación autónoma y diferenciada de cada una de ellas, que además respondería a las instrucciones de la normativa internacional al respecto; por el contrario, una confusión de ambas lo único que va a provocar son situaciones y soluciones inadecuadas, desproporcionadas y absolutamente injustas, incluso, en mi opinión, ilegales, aunque, eso sí, plenamente populistas y electoralistas. No quisiera entrar en ejercicios lingüísticos puramente demagógicos o que, nuevamente, a quienes defendemos la prioridad absoluta e irrenunciable de los principios y garantías fundamentales y básicos de un Estado de Derecho ${ }^{10}$, se nos acuse de dedicarnos a poner trabas "formales" a la solución "efectiva" de los problemas. Sobre todo, cuando esas presuntas "trabas formales" lo único que representan es el respeto de los derechos y libertades de los ciudadanos (de todos, los delincuentes y los no delincuentes) ${ }^{11}$, y cuando la "solución efectiva" de los problemas se acerca peligrosamente a un planteamiento maquiavélico de que el "fin justifica los medios", y a un Derecho penal de cuño autoritario ${ }^{12}$. Trataré, por ello, de justificar mis afirmaciones.

El art. 1 de la Declaración de Naciones Unidas sobre la eliminación de la violencia contra la mijer (Resolución de la Asamblea General 48/164, de 20 de Diciembre de

$1 / 2004$ circunscribe su objeto a la violencia que sufren las mujeres "como manifestación de la discriminación, la situación de desigualdad y las relaciones de poder de los hombres sobre las mujeres", lo cierto es que "desde el punto de vista penal los principales instrumentos para hacer frente a la violencia contra las mujeres siguen ligados al modelo de «violencia doméstica» que consagran los artículos 173.2 y 153 del Código penal”; en el mismo sentido, RAMÓN RIBAS, Violencia de género y violencia doméstica, cit., pág. 46; VILLACAMPA ESTIARTE, "El maltrato singular cualificado por razón de género. Debate acerca de su constitucionalidad", ", en Revista Electrónica de Derecho Penal y Criminología, 2007, pág. 18, http://criminet.ugr.es/recpc, 09-12 (2007), consultada el 25 de Octubre de 2008, quien, a pesar de defender la constitucionalidad de la Ley reconocer que "ciertamente, el concepto de violencia en que la ley piensa, traducido en las reformas penales que incorpora, se halla excesivamente circunscrito a las relaciones familiares o de pareja, y se aleja de concepciones más extensas contempladas en instrumentos internacionales"; de modo similar, MAQUEDA ABREU. "La violencia de género. Entre el concepto jurídico y la realidad social", en Revista Electrónica de Derecho Penal y Criminología, 2006, pág. 11, http://criminet.ugr.es/recpc, 08-02 (2006), consultada el 25 de Octubre de 2008, al afirmar que "...la violencia de género se presenta enmascarada bajo una referencia más amplia que la acaba asimilando a la violencia doméstica".

${ }^{10}$ Cfrs. BUSTOS RAMÍREZ/HORMAZÁBAL MALAREE, Lecciones de Derecho penal. Parte general, Madrid 2006, pág. 29.

${ }^{11}$ Como señala ZAFFARONI, El enemigo en Derecho penal, Dykinson, 2006, pág. 184, “...es un grosero error creer que el llamado discurso de las garantias es un lujo al que se puede renunciar en los tiempos de crisis y menos aún considerar que se trata de una tesis conservadora; por el contrario, por un lado debemos prevenirnos contra las reformas promovidas por las burocracias que se alimentan de la emergencia de turno presentándolas como postmodernas y por otro debemos cuidar ese discurso porque en los tiempos de crisis es la única garantía posible de la eficacia que puede pedirsele al derecho penal y al poder punitivo".

12 Como manifiesta FERRAJOLI "para la crisis del Derecho no existe otra respuesta que el Derecho mismo. Esto es así, puesto que el actual paradigma garantista del constitucionalismo democrático no sólo expresa un modelo de Derecho y de Estado, sino también un modelo de democracia, y por ello lo sostiene la fuerza de la razón y de los valores de la libertad, igualdad y justicia, cfrs. Derecho y Razón, Ed. Trotta, Madrid 1995, págs. 807 y ss. 
Núñez Castaño - La violencia doméstica en la legislación española...

1993), define la violencia contra la mujer como "todo acto de violencia basado en la pertenencia al sexo femenino que tenga o pueda tener como resultado un daño o sufrimiento físico, sexual o psicológico para las mujeres, inclusive las amenazas de tales actos, la coacción, la privación arbitraria de la libertad, tanto si se produce en la vida pública o privada".

Entiendo que la definición transcrita fundamenta la configuración de la violencia contra la mujer en un desprecio hacia su condición de mujer, en la existencia de un fin de subordinación, de reducción a una condición inferior a la de persona, en la "cosificación" de la mujer, considerándola como objeto disponible. Clara manifestación de este tipo de violencia son el acoso laboral, la trata de blancas o prostitución en su más amplia concepción, las mutilaciones genitales, y muchas otras prácticas socialmente consolidadas e, incluso aceptadas; y, obviamente, también las violencias que se producen, por estas mismas razones, contra la mujer en un entorno familiar o doméstico.

Otra cosa, claramente diferenciada aunque coincidente en algunos aspectos, es la "violencia doméstica" o "violencia intrafamiliar". En estas situaciones, en mi opinión, la violencia no encuentra su esencia fundamental en el hecho de ser una mujer la víctima de la misma, sino en el reparto de roles que se produce en toda estructura familiar, donde unos sujetos ejercen el papel rector o controlador y otros el papel de sometidos; reparto que se basa, no tanto en la naturaleza sexual de los sujetos involucrados, sino en la propia estructuración de la institución de la familia.

Ahora bien, llegados a este punto, resulta innegable que, ancestralmente, en un altísimo porcentaje, los roles dentro del entorno familiar se corresponden con el de hombre-dominador, mujer-sometida, derivado de costumbres y situaciones culturales, sociales y económicas ampliamente arraigadas ${ }^{13}$. Sin embargo, resulta igualmente innegable que el cambio social está variando radicalmente ese binomio. Y no sólo porque el "sometimiento" de la mujer vaya descendiendo poco a poco, debido fundamentalmente a su liberación en otros ámbitos sociales; sino, también, porque el concepto tradicional de familia ha variado sustancialmente, de manera que la estructura familiar ya no está compuesta, en exclusiva, por parejas heterosexuales (hombre-mujer), sino también, cada vez con mayor frecuencia, por parejas homosexuales (mujer-mujer, hombre-hombre), donde los roles (dominador, sometido) se reproducen de igual manera, y donde la violencia derivada, precisamente, de estos roles, se reproduce igualmente.

\footnotetext{
13 Así, afirma FARALDO CABANA, "Razones para la introducción de la perspectiva del género en el Derecho penal a través de la Ley Orgánica 1/2004, de 28 de Diciembre, de medidas de protección integral contra la violencia de género", en Revista Penal, no 17,2006 , pág. 82, que la violencia contra la mujer "... no es un problema de fuerza física, sino de actitud; la mujer está condicionada socialmente a aceptar que el varón utilice la violencia contra ella y no responde violentamente aunque tenga medios para ello u oportunidad para hacerlo. El hombre está condicionado socialmente a aceptar el uso de la violencia como medio adecuado para conseguir la obediencia de la mujer (esposa, compañera, novia o bija)".
} 
La violencia en el ámbito familiar o violencia doméstica no responde a motivaciones derivadas de un desprecio por razón de sexo (femenino, en este caso), sino a un sentimiento de propiedad y de superioridad por parte de un miembro de la unidad familiar hacia otro u otros (ya sea su pareja, hijos, padres, etc.). Esta violencia se dirige hacia las otras personas con la finalidad de mantener el statu quo, la situación de dominación, de sometimiento y de control. Nada que ver con la "violencia de género" o la "violencia contra la mujer", cuyo núcleo esencial radica en el desprecio hacia la mujer por el hecho de serlo, en considerarla carente de derechos, en rebajarla a la condición de objeto susceptible de ser utilizado o atacado por cualquiera.

Identificar violencia contra la mujer (o violencia de género) con violencia doméstica, implicaría dejar fuera de la protección penal supuestos de violencia derivada del sometimiento de un miembro de la pareja a otro miembro ${ }^{14}$. Obviamente, aunque están claramente conectados, no se puede aceptar una identificación plena de ambos fenómenos.

La violencia de género debe abarcar cualquier acto de violencia sufrido por una mujer en razón de su sexo, que tenga o pueda tener como resultado un daño físico, sexual o psicológico, y que abarca toda la gama de delitos contra las personas (vida, integridad física y/o psíquica, integridad moral, libertad, libertad sexual, intimidad, honor, etc.). Resulta obvio que este tipo de violencia se produce en el ámbito familiar con una elevada frecuencia, pero también, y no mucho menos frecuentemente, en el entorno laboral, escolar o cualquier otro ámbito social.

De hecho, la Exposición de Motivos de la L. O. 1/2004, de 28 de Diciembre, afirma que la violencia de género "se trata de una violencia que se dirige sobre las mujeres por el mismo hecho de serlo, por ser consideradas, por sus agresores, carentes de los derechos minimos de libertad, respeto y capacidad de decisión", entendiendo que el síndrome de la mujer maltratada consiste en "las agresiones sufridas por la mujer como consecuencia de los condicionantes socioculturales que actúan sobre el género masculino y femenino, situándola en una posición de subordinación al hombre y manifestada en los tres ámbitos básicos de relación de la persona: maltrato en el seno de las relaciones de pareja, agresión sexual en la vida social y acoso en el medio laboral".

\footnotetext{
${ }^{14}$ Esto es lo que está ocurriendo en el caso de violencias producidas entre parejas homosexuales, fundamentalmente masculinas. Concretamente, en España, se han producido varios casos en Abril de 2009, alguno de ellos que ha desembocado en la muerte, y sin embargo, las instituciones públicas, el delegado del Gobierno para la Violencia de Género, ha afirmado que esto no se trata de "Violencia de Género", en el sentido de poder aplicar la normativa derivada de la ley Orgánica $1 / 2004$, sino de Violencia doméstica, en un claro ejemplo de la confusión existente entre ambos conceptos en el legislador y gobierno español, vid. Periódico Público, 15 de Abril de 2009. La Ley Orgánica 1/2004 impide claramente la posibilidad de apreciar un sujeto pasivo masculino y, en mi opinión, también de un sujeto activo femenino.
} 
Núñez Castaño - La violencia doméstica en la legislación española...

Sin embargo, y a pesar de reconocer que la violencia de género se extiende a los tres ámbitos citados (familiar, laboral y social), el art. 1.1 de la Ley proclama de forma categórica que:

"La presente Ley tiene como objeto actuar contra la violencia que, como manifestación de la discriminación, la situación de desigualdad y las relaciones de poder de los hombres sobre las mujeres, se ejerce sobre estas por parte de quienes sean o hayan sido sus cónynges o de quienes están o hayan estado ligados a ellas por relaciones similares de afectividad, aún sin convivencia".

Consecuentemente, sobre la base de todo lo expuesto hasta ahora, a pesar de su denominación genérica (Ley Integral de Medidas de Protección contra la violencia de Género) e, incluso, a pesar de lo manifestado en la Exposición de Motivos, la L.O. 1/2004 sólo protege la violencia contra la mujer que se realice dentro de un determinado entorno, el doméstico o familiar. O dicho de otro modo, ex lege (art. 1.1. de la L.O. 1/2004) quedan excluidos del ámbito de aplicación los comportamientos violentos contra las mujeres que se realicen en el ámbito laboral y/o social; en todo caso, los que no pertenezcan al entorno familiar o doméstico.

En definitiva, como he manifestado con anterioridad, considero que se produce una confusión conceptual entre la violencia de género y la violencia doméstica que, como afirman MIRAT HERNÁNDEZ Y ARMENDÁRIZ LEÓN" ${ }^{15}$ "... ambos son fenómenos violentos, ambos se dan en el núcleo familiar, pero no toda violencia que se produce dentro de la familia es violencia de género, ni todos los actos de violencia de género se dan dentro del ámbito familiar".

De hecho, si la L.O. 1/2004 fuera realmente una Ley contra la violencia de género, debería amparar todo acto o comportamiento violento que atente contra la vida, integridad física y/o psíquica, moral, libertad (incluida la sexual), etc., que se realicen contra las mujeres por el mero hecho de serlo, y que se produzcan tanto dentro como fuera del hogar o de las relaciones familiares o asimiladas. En realidad, por lo que a la tutela penal se refiere, se trata de la regulación de supuestos de violencia doméstica con una protección especial y reforzada respecto de la mujer.

Pero es que, además, la Ley no sólo no es aplicable a todos los ámbitos donde la violencia de género pueda producirse, sino que tampoco regula todas las manifestaciones de violencia que puedan realizarse contra una mujer por el hecho de ser mujer. Si acudimos al articulado de esta Ley, en su Titulo IV relativo a la "Tutela penal", se establecen modificaciones respecto de los delitos de lesiones, malos tratos, amenazas, coacciones y vejaciones leves, pero se dejan sin regular específicamente supuestos tan típicamente característicos de la violencia de género como los relativos a los delitos contra la libertad sexual principalmente, a la

${ }^{15}$ MIRAT HERNÁNDEZ/ARMENDÁRIZ LEÓN, Violencia de género versus violencia doméstica, cit., pág. 113. 
intimidad, al honor, etc. ${ }^{16}$. De este modo, en mi opinión, no estamos sino ante una protección reforzada de la mujer en relación con la violencia doméstica o familiar.

No se puede negar que las mujeres, tal como reconocen distintos organismos internacionales, han sufrido, desde tiempos inmemoriales, graves situaciones de desigualdad, discriminación, vulneración de derechos y violencias por razón de la condición de ser mujer. Y es preciso hacer frente a este tipo de comportamientos, a fin de evitar que estas situaciones se sigan produciendo; hay que otorgar protección jurídica para hacer frente a la trata de blancas, a la prostitución coaccionada, a la explotación sexual, a las mutilaciones genitales, a los acosos sexuales y laborales, en definitiva, a todas las manifestaciones violentas de la desigualdad que hoy en día existen. Sin embargo, a nada de esto da respuesta la Ley de medidas de Protección Integral contra la Violencia de Género. Por el contrario, establece modificaciones que elevan desmesurada e injustificadamente la protección de la mujer cuando se realicen determinados comportamientos violentos dentro del entorno familiar; y realiza esta protección obviando que, como he afirmado con anterioridad, esta violencia no se produce tan sólo por el hecho de ser mujer, sino, fundamentalmente, por el rol de sometimiento que ocupa el sujeto que la padece, sea mujer o no. Es decir, obviando que lo que modifica en realidad son supuestos de Violencia doméstica, y no de Violencia de Género. Con ello, deja fuera del ámbito de protección de la mencionada Ley, comportamientos esencialmente idénticos a otros, pero en los que el sujeto pasivo no es mujer.

Esto es lo que ocurre, por ejemplo, y sin profundizar demasiado en su análisis, por cuanto no es objeto del presente trabajo, con el art. 153 del Código penal español, que ha resultado uno de los más conflictivos de la nueva regulación. En este precepto se castiga con pena de 6 meses a un año el maltrato simple $u$ ocasional, que no exige habitualidad ${ }^{17}$, es decir, a quien golpeare o maltratare de obra

${ }^{16}$ MIRAT HERNÁNDEZ/ARMENDÁRIZ LEÓN, Violencia de género versus Violencia doméstica, cit., págs. 113 a 116; BOLDOVA PASAMAR/RUEDA MARTIN, "Consideraciones políticocriminales en torno...", cit., pág. 18, donde afirman que en virtud del concepto ofrecido por la Ley Orgánica 1/2004 no se calificará como violencia e género “...la violencia laboral o docente ejercida sobre una mujer por quienes sostienen un vinculo laboral o docente con la víctima, prevaliéndose de una situación de superioridad. $O$, por ejemplo, tampoco será violencia de género la mutilación genital femenina sobre una adolescente de quince años de edad por parte de su padre".

${ }^{17}$ La ley Orgánica 11/2003, de 29 de Septiembre, de medidas concretas en materia de seguridad ciudadana, violencia doméstica e integración social de los extranjeros, reforma el sistema de represión penal existente hasta el momento en materia de violencia doméstica. En primer lugar, el cambio más llamativo, como veremos más adelante, consistió en reubicar el delito de violencia habitual o maltrato habitual, abandonando el Capítulo dedicado a las lesiones, y pasando a incluirse dentro de los delitos contra la integridad moral, como un segundo apartado del art. 173 del Código penal español. Pero la reforma realizada por esta Ley que ha suscitado más polémica, tanto doctrinal como jurisprudencial, ha sido la que introdujo el maltrato simple u ocasional en el art. 153, y que supuso convertir en delito una serie de conductas que tradicionalmente habían sido constitutivas de faltas (en concreto, falta de lesiones, falta de maltrato y falta de amenazas leves con armas y otros instrumentos peligrosos) siempre que se dirigieran contra un determinado grupo de personas (las recogidas en el art. 173.2 del Código penal) dentro de un contexto de violencia 
Núñez Castaño - La violencia doméstica en la legislación española...

sin causar lesión a quien sea o haya sido su esposa o mujer, o esté o haya estado ligada por análoga relación de afectividad. En resumen, a quien le dé una bofetada a su mujer o pareja o expareja (siempre que sea de sexo femenino) se le impondrá una pena mínima de seis meses; si esa misma bofetada se produce de la mujer hacia el hombre, o entre parejas homosexuales, fundamentalmente masculinas, la pena mínima será de tres meses. No hace falta un análisis más pormenorizado para poder afirmar categóricamente que, desde el punto de vista del principio de legalidad penal, de igualdad y de proporcionalidad, resulta difícilmente justificable la afirmación de que un hecho con idéntico desvalor de acción y de resultado, conlleve una diferencia tan notable de penalidad por el mero hecho de ser o no mujer la víctima del delito.

Mas paradójico, si cabe, resulta el art. 171.4 del Código penal español, donde se castiga con la misma pena de seis meses a un año a quien amenace de modo leve a quien sea o haya sido su esposa o mujer, o esté o haya estado ligado por análoga relación de afectividad, mientras que en el número 5 del mismo artículo impone la pena de tres meses a un año, a quien amenace con armas o instrumentos peligrosos a cualquiera de las demás personas incluidas en el art. 173.2, por ejemplo, marido o hijos menores. La situación se comenta por sí misma.

En mi opinión, esta regulación derivada de la "pretendida" Ley contra la violencia de género, que en realidad sólo hace referencia, y sesgada, a la violencia doméstica contra la mujer, no está reconociendo la igualdad entre hombres y mujeres, sino que, por el contrario, protegiendo, como lo hace, de una manera excesiva a quien considera el "sexo débil", está provocando desigualdades injustificadas con respecto de otros sujetos del entorno familiar que desempeñan el mismo rol que pueda desempeñar la mujer, al tiempo que adolece de un criticable y excesivo paternalismo que convierte a los sujetos hiperprotegidos (la mujer, en este caso) en una especie de sujetos indefensos. Una lucha por la igualdad mal entendida puede ser tan reprochable como el mantenimiento de desigualdades legales y sociales entre grupos de individuos, porque todo privilegio, en uno u otro sentido, determina, a mi entender, una discriminación.

Pese a todo esto, la Ley de medidas de Protección Integral contra la Violencia de Género ha sido avalada y defendida no sólo por el legislador y distintos organismos nacionales, sino, como ya señÁLAMOs, también por el Tribunal Constitucional. Y, consecuentemente, todas las reformas por ella

doméstica. Sin embargo, la característica esencial de la reforma efectuada en relación con este artículo radica en la eliminación del requisito de la habitualidad (que tradicionalmente había servido para justificar el castigo específico y autónomo de la violencia en el entorno familiar) constituyéndose por ello en una especie de maltrato simple donde la realización de un solo acto aislado de violencia en el entorno familiar sin resultado lesivo daba lugar a la imposición de una pena. Pero la escalada punitivista e hiperproteccionista en este ámbito aún no había terminado; así, la Ley orgánica 1/2004, sobre medidas de protección integral contra la Violencia de Género modificó nuevamente el art. 153 a fin de diferenciar el tratamiento penológico de las conductas en él recogidas en virtud de que la víctima fuese mujer o no. 
realizadas son plenamente válidas en la legislación española y, con ello, se pretende otorgar mayor protección a la mujer en determinadas situaciones de violencia ejercida contra ella, dentro del ámbito doméstico y/o familiar.

Sin embargo, y a pesar de ser, precisamente, el ámbito doméstico o de relaciones familiares o de convivencia, el núcleo esencial de los comportamientos regulados en la Ley, curiosamente tampoco se recoge referencia alguna al tipo delictivo que tradicionalmente castigaba estos comportamientos, esto es, el delito de violencia habitual en el ámbito doméstico, regulado en la actualidad en el art. 173.2 del Código penal, después de una sucesiva serie de reformas y traslados de ubicación sistemática en el Código penal. El análisis de algunas cuestiones relativas a este tipo delictivo concreto, será el objeto esencial de este trabajo.

\section{Evolución de la regulación legislativa del delito de violencia doméstica habitual}

Como acabo de señalar, la Ley Orgánica 1/2004 no realiza modificación alguna respecto del delito de violencia doméstica habitual. Sin embargo, lo cierto es que han sido muy diversas y variadas las reformas que este delito ha sufrido.

El delito de violencia doméstica habitual fue introducido en art. 425 del anterior Código penal (Texto Refundido del Código penal de 1973) ${ }^{18}$ mediante la Ley Orgánica 3/1989, de 21 de Junio, de actualización del Código penal. Posteriormente, el Código penal de 1995, reproduce de forma prácticamente idéntica la regulación en el art. 153 del Código penal ${ }^{19}$. De este modo, se incluía el delito de violencia doméstica habitual dentro de las lesiones, con lo cual dentro de los delitos contra la salud e integridad física.

Precisamente en este ámbito comienzan los problemas. Dada su ubicación sistemática, se suscitó una enorme controversia doctrinal y jurisprudencial en torno a cuál debiera ser el bien jurídico que se protegía en este tipo delictivo ${ }^{20}, \mathrm{y}$ que derivaría en problemas concursales y de delimitación de la conducta típica. Tanto la problemática derivada de la propia regulación del art. 153, como el

\footnotetext{
${ }^{18}$ El art. 425 del anterior Código penal establecía: "El que habitualmente, y con cualquier fin, ejerza violencia física sobre su cónynge o persona a la que estuviere unido por análoga relación de afectividad, así como sobre los hijos sujetos a la patria potestad, o pupilo, o menor o incapaz, sometido a su tutela o guarda de hecho, será castigado con la pena de arresto mayor".

${ }^{19}$ Originalmente, el Art., 153 del Código penal de 1995,establecía: "El que habitualmente ejerża violencia física sobre su cónyuge o persona a la que se halle ligado de forma estable por análoga relación de afectividad o sobre los hijos propios o del cónyuge conviviente, pupilos, ascendientes o incapaces que con el convivan o se hallen sujetos a la potestad, tutela, curatela o guarda de hecho de uno u otro, será castigado con la pena de prisión de seis meses a tres años, sin perjuicio de las penas que pudieran corresponder por el resultado que en cada caso, se causare".

${ }^{20}$ En relación con la polémica de la determinación del bien jurídico del delito recogido en el antiguo artículo 153, vid, por todos, NÚÑEZ CASTAÑO, El delito de malos tratos en el ámbito familiar, Aspectos fundamentales de la tipicidad, Valencia 2002, pags. 71 a 109.
} 
Núñez Castaño - La violencia doméstica en la legislación española...

incesante incremento del número de casos de violencia doméstica habitual, implicó una avalancha de reformas legislativas en esta materia que comenzaron con la Ley Orgánica 11/1999, de 30 de Abril, de modificación del Título VIII, del Libro II del Código penal (delitos contra la libertad e indemnidad sexuales) donde se establecían algunas modificaciones en materia procesal y de medidas cautelares respecto del delito de violencia doméstica. Sin embargo, la principal modificación del art. 153 en aquel momento, se realizó a raíz de la Ley Orgánica 14/1999, de 9 de Junio, de Modificación del Código penal en Materia de Protección a las víctimas de malos tratos y de la Ley de Enjuiciamiento Criminal, que supuso, entre otras reformas, la introducción de la violencia psíquica como modalidad típica, la ampliación del círculo de sujetos incluyendo no sólo a quien actualmente fuese el cónyuge o conviviente, sino también a la persona que, con anterioridad, hubiese sido su cónyuge o hubiera estado ligada al maltratador por análoga relación de afectividad, el establecimiento de un concepto legal de habitualidad atendiendo al número de actos de violencia que resulten acreditados y a la proximidad temporal de los mismos, la inclusión de reformas procesales, etc.

No obstante, a pesar de los esfuerzos legislativos, la realidad se imponía y los casos de violencia doméstica seguían creciendo de manera imparable. Por ello, el legislador, una vez más, a golpe de clamor social y mediático, procedió a una nueva reforma legislativa que supuso una auténtica revolución en esta materia implicando un giro radical, la Ley Orgánica 11/2003, de 29 de Septiembre, de medidas concretas en materia de seguridad ciudadana, violencia doméstica e integración social de los extranjeros. En concreto, de la reforma de esta Ley deben destacarse tres aspectos esenciales:

- en primer lugar, y sin duda la cuestión más controvertida de esta reforma, supone la conversión de la falta de lesiones, falta de malos tratos o de amenazas leves con armas, en un nuevo delito de maltrato en el que desaparecía el requisito de la habitualidad, recogido en el art. 153 del Código penal. Esta reforma fue, sin lugar a dudas, el comienzo de la grave controversia que existe en relación con la actual regulación de este tipo delictivo ${ }^{21}$.

- en segundo lugar, determina una ampliación del círculo de sujetos protegidos, incluyendo a todos los descendientes, ascendientes o hermanos, ya sean propios o del cónyuge o conviviente, así como a

\footnotetext{
${ }^{21}$ En relación con esta polémica, vid. por todos, MENDOZA CALDERÓN, "Hacia un Derecho penal sin fundamentación material del injusto", cit.; y también, GÓMEZ NAVAJAS, "La violencia en el ámbito familiar: ¿una reforma inacabada o inacabable?. Consideraciones sobre los artículos 153 y 173.2 del Código penal”, en Revista de Derecho y Proceso penal, nº 11, Enero 2004, págs. 30 a 33; CORTÉS BECHIARELLI, "Novedades legislativas en materia de maltrato doméstico (Ley Orgánica 11/2003, de 29 de Septiembre): propuestas de interpretación", en Estudios penales en recuerdo del Profesor Ruiz. Antón, Valencia 2004, págs. 241 y ss.; BOLDOVA PASAMAR/RUEDA MARTIN, "El nuevo tratamiento de la violencia habitual en el ámbito familiar, afectivo o similar tras las reformas del 2003 del Código penal español", en Revista de Derecho penal y Criminología, $2^{a}$ época, 2004, no 14 , págs. 19 y ss.
} 
cualquier persona integrada en el núcleo de convivencia familiar. Al mismo tiempo, en este ámbito se elimina el requisito de la convivencia para poder apreciar la concurrencia de violencia doméstica, y

- en tercer lugar, las conductas de violencia doméstica habitual pasan a contemplarse como delito contra la integridad moral, de manera que abandonan su ubicación en sede de lesiones, para configurar un nuevo delito contra la integridad moral regulado en el art. 173.2 del Código penal. Con ello, se daba respuesta a las demandas procedentes de un importante sector jurisprudencial y doctrinal ${ }^{22}$.

De este modo, el objeto de este trabajo lo constituye precisamente el análisis de algunas cuestiones derivadas de este último aspecto, es decir, del análisis del tipo delictivo contenido en el art. 173.2, tanto en relación a la determinación del bien jurídico protegido por el mismo, que por su ubicación sistemática debiera interpretarse como la integridad moral, como respecto a la delimitación de su conducta típica y de la necesidad o no de una regulación autónoma en esta materia, después de las sucesivas reformas y contrarreformas que en este ámbito se han producido. Reformas que, en mi opinión suponen, por la grave problemática interpretativa y de aplicación que van a provocar un proceder legislativo falto de reflexión y análisis, respondiendo a "impulsos" derivados directamente de la presión social y mediática, y que se reflejan en una desmesurada intensificación de la intervención penal en esta materia. Intensificación desmesurada e ineficaz, porque ni de lejos ha supuesto una solución a este problema.

\section{El bien jurídico protegido en el art. 173.2 del Código penal}

Habitualmente, cuando la doctrina se enfrenta al estudio de alguno de los tipos que conforman la Parte Especial del Derecho penal, la primera necesidad que surge es la determinación o, la mayor parte de las veces en los últimos tiempos, el intento de determinar cuál sea el bien jurídico que el mismo protege $e^{23}$, a fin de que,

\footnotetext{
${ }^{22}$ En este sentido, la propuesta realizada por MORILLAS CUEVA ha sido plenamente recogida por el legislador, vid., "Respuestas del Código penal ante la violencia doméstica. Propuestas de reforma”, en Estudios penales sobre la Violencia doméstica, Morillas Cueva (coord..), Madrid 2002, pág. 672.

${ }^{23}$ Determinación que es imprescindible desde el planteamiento de un Derecho penal cuya principal función es la protección de bienes jurídicos, tal como señalan BUSTOS RAMÍREZ/HORMAZÁBAL MALAREE, Lecciones de derecho penal, cit., págs. 71 y 72, “...la necesidad de identificar el objeto protegido por el sistema penal tiene un claro origen liberal y garantista (...) cuyo objetivo era limitar el poder de definir conductas criminales del Estado a la exclusiva protección de bienes jurídicos..."; en el mismo sentido, ya previamente, HASSEMER, "Crisis y características del moderno Derecho penal", en Actualidad penal, 1993, págs. 638 y ss.; MUÑOZ CONDE, Derecho penal, Parte General, $7^{\mathrm{a}}$ ed., Valencia 2007, págs. 76 a 81, donde afirma que “....se puede decir que las leyes penales que no protegen bienes jurídicos son nulas por arbitrarias o por infringir el principio de intervención minima del Derecho penal"; NÚÑEZ CASTAÑO, "Las transformaciones sociales y el Derecho penal: del estado liberal al Derecho penal de enemigos", en Problemas actuales del Derecho penal y de la
} 
Núñez Castaño - La violencia doméstica en la legislación española...

tal como señalan BUSTOS RAMÍREZ y HORMAZÁBAL MALAREE se pueda legitimar la intervención estatal en un determinado ámbito ${ }^{24}$. Para ello, es preciso ab initio, constatar dos extremos: en primer lugar, la necesidad de protección penal para garantizar la salvaguarda del mencionado bien jurídico ante la comisión de determinados tipos de comportamientos que pudieran lesionarlo ${ }^{25}$; y, en segundo lugar, la inexistencia hasta ese momento de una posible respuesta penal frente a esas conductas lesivas.

Como ya hemos dicho, la violencia en el ámbito familiar no es un fenómeno reciente, sin embargo, el "interés" legislativo por este tipo de situaciones sí se ha incrementado en los últimos tiempos ${ }^{26}$, de manera que el legislador ha tratado de aportar soluciones "específicas" para este tipo de situaciones. Lo cierto, es que el Código penal siempre ha castigado los actos de violencia contra las personas (mujeres y hombres, dentro y fuera de la familia) mediante la protección de la vida, la integridad física y/o psíquica, la libertad en todas sus manifestaciones, el honor, etc. a través de los delitos clásicos de homicidio, lesiones, agresiones sexuales, amenazas, coacciones, injurias, etc., e incluso el castigo de comportamientos más leves a través de las correspondientes faltas o la falta de maltrato de obra ${ }^{27}$.

Sin embargo, este tipo de comportamientos cuando son realizados dentro de un determinado entorno, como es el doméstico o familiar, progresivamente y a partir de sucesivas reformas penales pasarán a tener un tratamiento autónomo diferenciado, aunque no incompatible, del resto de violencias hacia las personas. La pregunta resulta evidente: ¿cuál es la razón por la cual se penaliza de manera autónoma y más grave, hechos que esencialmente son idénticos pero que se producen entre determinados sujetos?

Se trata, por tanto, de identificar un interés específico, un bien jurídico, diferenciado de los tradicionales que sirva de fundamento para justificar la específica regulación existente en esta materia. Desde este punto de partida, la identificación de cual pudiera ser el bien jurídico protegido en el delito de violencia doméstica habitual ha dado lugar a múltiples discusiones doctrinales derivadas

\footnotetext{
Criminologia. Estudios penales en memoria de la Profesora Dra. Maria del Mar Diaz Pita, Muñoz Conde (direct.), Valencia 2008, pág. 117.

${ }^{24}$ Cfrs. BUSTOS RAMÍREZ/HORMAZÁBAL MALAREE, Nuevo sistema de Derecho penal, Madrid 2004, pág. 32.

${ }^{25}$ Cfrs. BUSTOS RAMÍREZ/HORMAZÁBAL MALAREE, ult. op. cit., págs. 33 y ss; los mismo, Lecciones de Derecho penal, cit., págs. 73 y ss., y 179 y ss.

${ }^{26}$ Así, la introducción del delito de malos tratos en el ámbito familiar se realiza por la L.O. 3/1989, y sufre sucesivas y continuas modificaciones hasta llegar a la actual regulación derivada de la L. O. 1/2004 de Medidas de Protección integral contra la violencia de Género.

${ }^{27}$ BOLEA BARDÓN, "En los límites del Derecho penal frente a la violencia doméstica y de género", Revista Electrónica de Derecho Penal y Criminología, no 9, 2007, pág. 5, http://criminet.ugr.es/recpc, 09-02 (2007), consultada el 25 de Octubre de 2008.
} 
esencialmente de su anterior ubicación en el Código penal ${ }^{28}$. A fin de tratar de responder a esta situación, considero que debiéramos empezar por identificar qué se pretende proteger o evitar con la criminalización autónoma de los malos tratos en el ámbito doméstico.

Resulta obvio que el problema de la violencia doméstica tiene una relevancia y trascendencia innegable en la sociedad actual, principalmente a causa de la alarma social que este tipo de conductas representan; del mismo modo resulta innegable la necesidad de una respuesta por parte del Estado, y consecuentemente un apoyo y respaldo a las víctimas de este tipo de comportamientos. Y es perfectamente factible que esta respuesta se otorgue por medio del Derecho penal, siempre y cuando ello sea preciso. El recurso al Derecho penal debe producirse cuando sea absoluta y estrictamente necesario, debiendo evitarse arrebatos emotivos y pasionales, que vulneren los principios básicos del Ordenamiento jurídico penal, y que tengan como resultado y meta más directa el acallar las voces sociales de protesta y no la consecución de soluciones para este grave problema.

Sin embargo, la realidad dista bastante de lo que acabamos de afirmar. Tal como afirman BUSTOS RAMÍREZ y HORMAZÁBAL MALAREE ${ }^{29}$, “.. hay una constante demanda social de cárcel ante cualquier conflicto que se presente, alimentada por los propios poderes públicos y los medios de comunicación. Esta demanda social por la intervención penal es rápida e irreflexivamente atendida por los poderes públicos. Por una parte le da a la intervención penal una pátina de democracia y por la otra, como es muy fácil de satisfacer y da una apariencia de preocupación por solucionar el conflicto, se constituye en una fuente para la obtención de votos en las periódicas elecciones donde se han de renovar dichos poderes".

Ab initio no niego la necesidad de que el Derecho penal tipifique de forma autónoma este tipo de comportamientos, siempre y cuando se tenga presente que para regular nuevas conductas delictivas no es suficiente con que se eleven voces, incluso acaloradas, desde determinados sectores sociales, ni que se manejen escandalosos datos estadísticos sino que es necesario que se constate el cumplimiento de las exigencias y requisitos que se derivan del más estricto respeto a los principios de legalidad e intervención mínima; y entre ellos se encuentra la delimitación del contenido de un determinado bien jurídico que no esté recibiendo protección del Derecho penal de manera que existan espacios sin protección penal que justifiquen la creación de un delito autónomo. Por el contrario, si los comportamientos que pretenden castigarse o los bienes que pretenden protegerse están ya recogidos en la legislación penal, la regulación autónoma no se encuentra justificada.

\footnotetext{
28 Una exposición de todas las posturas doctrinales al respecto puede verse en NÚÑEZ CASTAÑO, El delito de malos tratos en el ámbito familiar: aspectos fundamentales de la tipicidad, Valencia 2002, págs. 71 y ss.

${ }^{29}$ Cfrs. BUSTOS RAMÍREZ/HORMAZÁBAL MALAREE, Lecciones de derecho penal, cit., pág. 25.
} 
Núñez Castaño - La violencia doméstica en la legislación española...

Dicho de otro modo, si lo que pretende castigarse en este ámbito de la violencia habitual son las muertes, lesiones, injurias, violaciones, amenazas, etc., ya sean consumadas ya intentadas porque no hayan supuesto la lesión efectiva del bien jurídico en concreto siempre que se produjeran entre determinado grupo de sujetos especialmente vinculados entre sí, la específica tipificación no resultaría legitima por cuanto se estaría protegiendo lo ya protegido, y sería suficiente con aplicar los tipos penales existentes para dar adecuada respuesta a estas conductas.

Ya con la anterior regulación del delito de violencia doméstica habitual ${ }^{30}$ existía acuerdo tanto doctrinal ${ }^{31}$ como jurisprudencial ${ }^{32}$ respecto a que con este tipo delictivo se castigaba algo más que los concretos actos de violencia, es decir, lo realmente representativo de estas conductas radicaba en que la repetición de los comportamientos violentos creaba un clima de violencia permanente, de maltrato sistemático, que implica que la víctima viva atemorizada, angustiada, sometida a una voluntad ajena que la humilla y la degrada. En definitiva, lo que se pretende sancionar es la humillación y envilecimiento que supone el vivir permanentemente sometido a una situación de temor por un reiterado maltrato ${ }^{33}$, tratada como si fuera un objeto, lo que supone una reducción a una cualidad inferior a la de persona.

Respondiendo a este acuerdo respecto del núcleo esencial del castigo autónomo de las conductas de violencia habitual en el ámbito doméstico, el legislador del 2003, ubicó este tipo de comportamientos junto con los atentados contra la integridad moral; con ello, de una interpretación sistemática se deriva necesariamente que este debe ser el bien jurídico a protegerse por el tipo delictivo recogido en el art. 173.2 del Código penal. Y ello implica dos cosas, en primer lugar, que para poder aplicarlo a las conductas violentas realizadas en el ámbito doméstico es necesario que éstas supongan un ataque la integridad moral, y en segundo lugar, la necesidad de diferenciarlo del atentado genérico contra la

\footnotetext{
30 Antes de la Ley Orgánica 11/2003, de 29 de Septiembre, de medidas concretas en materia de seguridad ciudadana, violencia de género e integración social de los extranjeros, el delito que estamos analizando se encontraba ubicado en el art. 153 del Código penal dentro del titulo de los Delitos contra la salud e integridad física y/o psíquica.

31 MARÍN DE ESPINOSA CEBALLOS, La violencia doméstica. Análisis sociológico, dogmático y de derecho comparado, Granada, 2001, págs. 230 y ss.; OLMEDO CARDENETE, El delito de violencia habitual en el ámbito doméstico: análisis teórico y jurisprudencial, Barcelona, 2001, pág. 64; NÚÑEZ CASTAÑO, El delito de malos tratos en el ámbito familiar, cit., págs. 90 y ss..

32 Así, las Sentencias del Tribunal Supremo de 17 de Abril, de 1997, de 24 de Junio, 7 de Julio y 7 de Septiembre de 2000, y de 10 de Enero de 2002, entre otras.

33 Justamente este planteamiento sirve para justificar la interpretación de que la habitualidad regulada en el párrafo $3^{\circ}$ del art. 173 no supone una vulneración de los principios penales básicos, como puede ser el ne bis in idem, sino que debe ser interpretada en el sentido de que los distintos actos de violencia sirvan para acreditar la existencia de un clima de violencia, de una situación de maltrato reiterado. De este modo no se valoran nuevamente los distintos ataques violentos, sino la significación que la reiteración de los mismos representa para la relación de los sujetos afectados. Así se manifiesta también la Fiscalia General del Estado, en su Circular 4/2003, de 30 de Diciembre, sobre nuevos instrumentos jurídicos en la persecución de la violencia doméstica.
} 
integridad moral recogido en el número 1 del mencionado artículo. Es decir, es necesario determinar si los comportamientos descritos efectivamente suponen un atentado a la integridad moral, así como establecer las diferencias, si es que las hubiere, entre las conductas incluidas en el número primero y las recogidas en el número 2 del art. 173.

\section{La integridad moral como bien jurídico protegido del art. 173 del Código penal}

El Código penal de 1995 introdujo por primera vez en la historia del Derecho penal español un Título dedicado a los delitos contra la integridad moral. Por una parte hacia referencia a un tipo delictivo históricamente contenido en nuestro ordenamiento jurídico, como es el caso de la tortura ${ }^{34}$, y por otra, a unos tipos de nueva regulación que denomina de forma genérica "otros delitos contra la integridad moral".

Esta denominación legislativa conlleva en primer lugar la afirmación de que el bien jurídico protegido en el delito de tortura es el mismo que el que se protege con "esos otros ataques contra la integridad moral", con lo cual, nos da una primera pista de que la integridad moral subyace como objeto de protección de los comportamientos recogidos en el Título VII. En realidad, existe cierto nivel de consenso en el sector mayoritario de la doctrina penal española en considerar que

\footnotetext{
34 Sobre la evolución legislativa del delito de tortura, vid., entre otros, MUÑOZ SÁNCHEZ, Los delitos contra la integridad moral, Valencia 1999, págs. 13 a 17; MAQUEDA ABREU, "La tortura y otros tratos inhumanos y degradantes", en Anuario de Derecho penal y Ciencias penales, 1986; BARQUÍN SANZ, Los delitos de tortura y tratos inbumanos o degradantes, Madrid 1992.
} 
Núñez Castaño - La violencia doméstica en la legislación española...

la integridad mora $P^{55}$ es el bien jurídico protegido en el mencionado Título, y respecto de todas las conductas en él recogidas ${ }^{36}$.

Se trata, por tanto, de delimitar que debe entenderse por integridad moral. Y aquí es donde la doctrina no es unánime.

Afirma DÍAZ PITA ${ }^{37}$, que la integridad moral es un bien jurídico difuso que arranca del concepto de dignidad humana, distinto de éste y que no puede ser identificado con la integridad psíquica, ya que ésta, al igual que la física, forma parte del concepto de salud, por lo que los ataques contra la misma obtendrían respuesta en los delitos de lesiones, privando a los delitos contra la integridad moral de su razón de $\operatorname{ser}^{38}$. Y que tampoco puede ser concebida como un derecho

\footnotetext{
${ }^{35}$ No obstante, hay que señalar que algún autor ha manifestado que el bien jurídico protegido en el delito de tortura es la dignidad, en este sentido, BARQUÍN SANZ, Los delitos de tortura, cit., pág. 230 y ss., quien admite esta posibilidad dado que "la multiplicidad de facetas del concepto de dignidad es, a nuestro modo de ver, lo que lo hace idóneo para sintetizar en una solo idea un bien jurídico tan difícil de aprehender como el del tipo básico de tortura y tratos inbumanos o degradantes", de tal modo que "...en el tipo básico de tortura y malos tratos, la dignidad ocupa ese lugar preeminente y se debe designar, por tanto, como bien jurídico protegido". Considero que en la interpretación que realiza BARQUÍN SANZ se produce una confusión entre lo que es un principio inspirador del ordenamiento jurídico y fundamento del mismo (la dignidad) con lo que son las diversas manifestaciones de ese principio, esto es, los derechos fundamentales, valores o bienes que deben ser protegidos (los distintos bienes jurídicopenales: vida, integridad, libertad, seguridad, etc.) y que constituyen el núcleo de protección de los distintos tipos penales. Así, entiendo que un atentado a la dignidad humana sólo es posible a través de la agresión de alguno de los derechos fundamentales en que aquélla se manifiesta, sin que haya espacio para una lesión a la dignidad que no conlleve algún atentado a otro bien jurídico, y a la inversa; y ello, porque no hay más vida o integridad física, merecedora y necesitada de protección, que la vida o integridad física digna. Respecto a mi postura a este respecto, y los argumentos para mantenerla, cfrs. NÚÑEZ CASTAÑO, El delito de malos tratos en el ámbito familiar. Aspectos fundamentales de la tipicidad, Valencia 2002, págs. 75 a 79, y la bibliografía allí citada.

36 MUÑOZ CONDE, Derecho penal. Parte Especial, $16^{\text {a }}$ ed., Valencia 2007, págs. 180-181; LÓPEZ GARRIDO/GARCÍA ARÁN, El Código penal de 1995 y la voluntad del legislador. Comentario al texto y debate parlamentario, Madrid 1996, pág. 105; RODRÍGUEZ MESA, Torturas y otros delitos contra la integridad moral cometidos por funcionarios públicos, Granada, 2000, pág. 174; MUÑOZ SÁNCHEZ, Los delitos contra la integridad moral, cit., pág. 23; DEL ROSAL BLASCO, "Torturas y otros delitos contra la integridad moral en el Código penal de 1995", en La ciencia del Derecho penal ante el nuevo siglo, Libro Homenaje al Profesor Cerezo Mir, Diez Ripollés/Romeo Casabona/Gracia Martín/Higuera Guimerá (editores), Madrid 2002, pág. 1232-1233, quien, no obstante, afirma que hay que matizar que la integridad moral en si misma sería el sustrato material sobre el que recae la acción, mientras que el derecho a la integridad moral, entendido como conjunto de facultades de decisión y disposición que el sujeto tiene sobre dicho sustrato "la auténtica entidad valorativa objeto de tutela en dicho título".

${ }^{37}$ DÍAZ PITA, "El bien jurídico protegido en los nuevos delitos de tortura y atentado contra la integridad moral”, en Estudios penales y criminológicos, n XX, 1997, pág. 50 y ss.

${ }^{38}$ De hecho, DÍAZ PITA, op. cit., pág. 95 afirma que el bien jurídico integridad moral aparece como residual respecto del bien jurídico integridad física entendido como salud, considerando que la integridad moral entraría en juego en aquellos supuestos en los que se produzca un menoscabo de la salud física o psíquica, pero sin entidad suficiente para ser calificado de lesiones. No comparto, sin embargo, este planteamiento, dado que lo realmente característico de la integridad moral como bien jurídico es la situación de humillación, envilecimiento y/o el clima de terror en el
} 
de los ciudadanos a actuar conforme a su voluntad e ideas, ya que este derecho se encuentra protegido en otros tipos penales, como pueden ser los delitos contra la libertad (en su más amplia acepción) ${ }^{39}$. Sobre esta base, y atendiendo a la descripción típica que en el art. 173 se realiza de los atentados contra la integridad moral $^{40}$, entiende DÍAZ PITA ${ }^{41}$ que el derecho a la integridad moral es el derecho de toda persona a recibir un trato acorde con su condición de ser humano libre y digno, y ver respetadas su personalidad y voluntad: a no ser degradado a una condición inferior a la de persona.

En una línea similar mantiene MUÑOZ SÁNCHEZ"2 que "el contenido de la integridad moral es el derecho de la persona a no sufrir sensaciones de dolor o sufrimientos físicos o psiquicos bumillantes, vejatorios o envilecedores" ${ }^{\text {,3 }}$.

De igual modo, podemos reflejar que la jurisprudencia ha centrado el contenido de la integridad moral en la delimitación de las conductas típicas recogidas en el Título VII del Código penal. Así, por ejemplo, en la Sentencia de 22 de Febrero de 2005 se señala que la integridad moral estaría compuesta por vía negativa por una serie de elementos subjetivos, tales como la humillación o vejación sufrida por la víctima que se ve tratada de forma instrumental y desprovista de su dignidad, pudiendo además, concurrir la nota de dolor físico, y también por elementos objetivos en referencia a la forma y modo en que se realiza

que se encuentran las personas, con independencia de los actos concretos que puedan realizarse para provocarlo. Es decir, si los concretos actos de violencia realizados pueden incluirse en alguno de los tipos penales existentes, serían castigados conforme a ellos, y el art. 173 se aplicaría cuando la realización de las conductas violentas provocase la situación de humillación y envilecimiento, incluso pudiendo castigarse autónomamente ambas situaciones tal como permite el art. 177 del Código penal.

${ }^{39}$ DÍAZ PITA, op. cit., págs. 50 y ss; MUÑOZ CONDE, Derecho penal, Parte especial, 16ª ed., cit., págs. 180 y ss.

40 Así, afirma que lo que sea integridad moral resulta más fácil de determinar en relación con la tortura, ya que esto permite acudir a las precisiones formuladas por el Tribunal Europeo de Derechos humanos (Sentencia de 25 de abril de 1978) y recogidas por el Tribunal Constitucional (SSRC 120/1990, 57/1994) según las cuales la tortura, los tratos inhumanos y los tratos degradantes "son nociones graduadas de una misma escala que en todos sus tramos denotan causación sean cuales sean los fines, de padecimientos físicos o psíquicos ilicitos e infligidos de modo vejatorio....y con esa propia intención de vejar y doblegar la voluntad del sujeto paciente" (STC 215/1994). Este planteamiento, ha permitido que la doctrina entienda por trato degradante, por ejemplo, "la provocación de padecimientos físicos o psíquicos vejatorios”, cfrs. LÓPEZ GARRIDO/GARCÍA ARÁN, El Código penal de 1995, cit., pág. 106.

${ }^{41}$ Cfrs. DÍAZ PITA, "El bien jurídico protegido en los nuevos delitos de tortura y atentado contra la integridad moral", cit., págs. 84-86 y 95.

${ }^{42}$ Cfrs. MUÑOZ SÁNCHEZ, Los delitos contra la integridad moral, Valencia 1999, pág. 24.

43 PÉREZ ALONSO, "Los nuevos delitos contra la integridad moral en el Código penal de 1995", en Revista de la Facultad de Derecho de la Universidad de Granada, $3^{\mathrm{a}}$ época, no 2, 1999, pág. 165 entiende que la integridad moral es el derecho a no ser reducido a la condición de mera cosa; GRIMA LIZANDRA, Los delitos de tortura y tratos degradantes por funcionarios públicos, Valencia 1998, pág. 68 lo interpreta como "el derecho a no ser tratado como un objeto, como una cosa, sino como un sujeto y ser racional capaz de regirse por normas". 
Núñez Castaño - La violencia doméstica en la legislación española...

el ataque. De este modo señala que los elementos que conforman el concepto de atentado contra la integridad moral serían: a) un acto de claro e inequívoco contenido vejatorio para el sujeto pasivo, b) la concurrencia de un padecimiento físico o psíquico y c) que el comportamiento sea degradante y humillante para la personavictima $^{44}$. En esta línea, la Sentencia de 8 de Mayo de 2002 afirma que podrán ser integradas dentro de los ataques contra la integridad moral aquellas conductas susceptibles de producir en las víctimas "sentimientos de terror, de angustia y de inferioridad susceptibles de bumillarles, de envilecerles y de quebrantar, en su caso, su resistencia fisica y moral ${ }^{\prime 45}$.

Sobre la base de lo dicho hasta el momento, considero que lo que da verdadera autonomía al concepto de integridad moral es el sentimiento de humillación y vejación que los atentados, los distintos comportamientos violentos realizados, ocasionan en el sujeto pasivo ${ }^{46}$, que van a provocar un sentimiento de inferioridad y de angustia, derivado precisamente de los comportamientos degradantes, tal y como se deduce de la redacción del párrafo primero del art. 173 del Código penal.

El problema al que nos enfrentamos ahora radica en determinar si los comportamientos descritos en el párrafo segundo, son adecuados para vulnerar o no el bien jurídico integridad moral, provocando este sentimiento de humillación, vejación y angustia, que se constituyen en las notas esenciales del mismo.

\section{La integridad moral como bien jurídico del delito de violencia habitual}

El delito de violencia habitual fue incluido en nuestro Código penal a raíz de la reforma del Código penal operada por la Ley Orgánica 3/1989, de 21 de Junio, en el art. 425, ubicado en sede de lesiones. Con la aprobación del Código penal de 1995, pasa a estar recogido en el art. 153 (y la falta en el art. 617.2) del Código penal, manteniéndose dentro del Título dedicado a las lesiones. Desde entonces hasta el momento actual ha sufrido innumerables reformas ${ }^{47}$, la principal de las

\footnotetext{
${ }^{44}$ Idéntica afirmación en las Sentencias del Tribunal Supremo de 16 de Abril de 2003 y de 25 de Septiembre de 2007. En sentido similar la Sentencia del Tribunal Supremo de 5 de enero de 2007 considera autores de un delito contra la integridad moral a quienes desarrollan una actitud tendente a vejar y humillar con comportamientos crueles e inhumanos.

${ }^{45}$ En este mismo sentido, vid. Sentencias del Tribunal Supremo de 29 de Septiembre de 1998 y 2 de Abril de 2003, entre otras.

${ }^{46}$ Cfrs. NÚÑEZ CASTAÑO, El delito de malos tratos en el ámbito familiar, cit., pág. 91.

47 En materia de violencia en el ámbito familiar se han producido sucesivas reformas: L.O. 11/1999, de 30 de Abril, de Modificación del Título VIII del Libro II de Código penal; L.O. 14/1999, de 9 de Junio, de Modificación del Código penal en Materia de Protección a las víctimas de malos tratos y de la Ley de Enjuiciamiento Criminal; L.O. 11/2003, de 29 de Septiembre, de medidas concretas en materia de seguridad ciudadana, violencia doméstica e integración social de
} 
REJ - Revista de Estudios de la Justicia - No 12 - Año 2010

cuales, en la materia que nos ocupa, (aparte de la Ley 1/2004) es la realizada por la Ley 11/2003 sobre medidas concretas en materia de seguridad ciudadana, violencia doméstica e integración social de los extranjeros. En ese momento, el delito de violencia habitual se traslada al art. 173, incluyendo en el mismo dos números más, y el 153 regula una suerte de "maltrato simple" entre determinadas personas.

Como ya hemos señalado, desde su primera regulación, una de las principales polémicas en relación con el delito de violencia habitual radica en la determinación de cuál sería el bien jurídico protegido en el mismo; polémica derivada principalmente de su ubicación dentro del Título dedicado a las lesiones ${ }^{48}$. Sin embargo, el cambio efectuado por la Ley 11/2003 supuso un cambio en los parámetros que regulaban esta materia al incluir las conductas de violencia habitual en el ámbito doméstico en el art. 173 del Código penal, ubicado en el Título VII bajo la rúbrica "De las torturas y otros delitos contra la integridad moral". De este modo, la opción legislativa ha entendido, tal como ya lo había hecho anteriormente la jurisprudencia ${ }^{49}$ y un sector de la doctrina ${ }^{50}$, que el bien jurídico que se protegía, ya no era la salud e integridad física o psíquica, sino otro diverso: la integridad moral.

los extranjeros; y por último(¿?) L.O. 1/2004, de 28 de diciembre, de Medidas de Protección Integral contra la Violencia de Género.

48 Sobre la polémica en relación con la concreción del bien jurídico protegido en el anterior art. 153 del Código penal, vid. NÚÑEZ CASTAÑO, El delito de malos tratos en el ámbito familiar, cit., págs. 71 a 106; GARCÍA ÁLVAREZ/DEL CARPIO DELGADO, El delito de malos tratos en el ámbito familiar. Problemas fundamentales, Valencia 1999, págs. 20 y ss; ACALE SÁNCHEZ, El delito de malos tratos físicos y psíquicos en el ámbito familiar, Valencia 2000, págs. 122 y ss; CORTÉS BECHIARELLI, El delito de malos tratos familiares. Nueva regulación, Madrid-Barcelona, 2000, págs. 42 y ss.; OLMEDO CARDENETE, El delito de violencia habitual, cit., págs. 27 y ss.; MARÍN DE ESPINOSA CEBALLOS, La violencia doméstica, cit., págs. 147 y ss.

${ }^{49}$ Vid. STS de 26 de junio de 2000, 20 de diciembre de 1996, 24 de Junio de 2000 y 22 de enero de 2002; en el mismo sentido, la Audiencia Provincial de Barcelona, en su Sentencia de 17 de Abril de 2000 afirma que "en todo supuesto de malos tratos entre parejas, lo que en realidad se constata es un desprecio a la mujer, a la que considera inferior al hombre y por tanto obligada a someterse a los dictados de este, lo que se busca con el maltrato, ya sea físico o psíquico es humillar a la mujer, para forzar su voluntad, y conseguir su sometimiento por medio del miedo que nace en la mujer, y ello evidentemente encaja en lo que se define como violación de la integridad moral. La mujer mediante los malos tratos a que la somete su pareja resulta degradada, vejada y bumillada".

En la misma línea, la Circular 1/1998 de la Fiscalía General del Estado, advierte que la ubicación sistemática dentro de los delitos de lesiones ha suscitado un erróneo entendimiento de algunas cuestiones que afectan al tipo, dado que el art. 153 (anterior a la Ley 11/2003) “...no pretende únicamente la protección de la vida, salud o integridad física de las personas, sino que tutela, además y esencialmente, otros bienes necesitados de protección que podrán reconducirse al ámbito de protección de los arts. 15 y 39 de la Constitución: la integridad moral o el derecho a no ser sometido a trato inhumano o degradante (...)”.

50 TAMARIT SUMALLA, Comentarios al Código penal de 1995, en Quintero Olivares y otros, $2^{\mathrm{a}}$ ed., Elcano 2001, pág. 751; CAMPOS CRISTÓBAL, Problemas que plantea la nueva regulación de los malos tratos, cit., pág.20; MARÍN DE ESPINOSA CEBALLOS, La violencia doméstica, cit., pág. 194; OLMEDO CARDENETE, El delito de violencia habitual en el ámbito doméstico, cit., pags. 42-48; GÓMEZ RIVERO, "Algunos aspectos del delito de malos tratos”, en Revista penal, no 6, Julio 2000; MORILLAS CUEVA, "Respuestas del Código penal ante la violencia doméstica”, cit., pág. 672. 
Núñez Castaño - La violencia doméstica en la legislación española...

El art. 173 se configura como un delito en el cual quedan incluidas todas aquellas conductas que menoscaben gravemente la integridad moral, en el sentido de que humillen, envilezcan, degraden e instrumentalicen al sujeto que lo padece, reduciéndolo a una condición inferior a la de persona; en definitiva, creando un clima de inferioridad, humillación y temor, que "cosifica" a la víctima del mismo y le hace vivir una situación de tensión y miedo ${ }^{51}$. Partiendo de esta concepción, se trata de determinar si las conductas de violencia habitual responden a esta descripción.

Como ya hemos manifestado reiteradamente, con la anterior regulación del delito de violencia habitual, un importante sector de la doctrina había mantenido que el bien jurídico que se protegía era la integridad moral, afirmación que se ha visto corroborada por la modificación legislativa. La base fundamental radicaba en la afirmación de que las conductas de violencia habitual en el ámbito doméstico encontraban su fundamento, su esencia, no en los concretos actos de violencia física y/o psíquica realizados, sino en la reiteración, en la repetición de los mismos que provocan en quien los sufre una situación de miedo y de tensión, una atmosfera de angustia y de constante temor, que suponen para la víctima una degradación, humillación y envilecimiento que se prolonga en el tiempo, quedando rebajada a un condición inferior a la de persona ${ }^{52}$. Como acertadamente afirma RAMÓN RIBAS 53 "...es la suma de todas esas horas, de todos esos días, la que constituye el injusto del delito de violencia habitual". En el mismo sentido, OLMEDO CARDENETE" mantiene que "la búsqueda del resultado material no tiene que centrarse individualizadamente en cada uno de los actos de violencia sino, por el contrario, en el efecto que sobre la víctima despliega el ejercicio sistemático de la violencia física o psíquica. Y para su concreción, desgraciadamente, basta con remitirse a las consecuencias que física y psíquicamente comporta el sindrome de la mujer maltratada ${ }^{155}$.

\footnotetext{
51 Como dice MARÍN DE ESPINOSA CEBALLOS, La violencia doméstica, cit., pág. 191, "la integridad moral se contempla «como el derecho a no ser tratado como un objeto, como una cosa, sino como sujeto y ser racional capaz de regirse por normas»".

52 En este sentido, cfrs. MARÍN DE ESPINOSA CEBALLOS, La violencia doméstica, cit., págs. 192 y 193; RAMÓN RIBAS, Violencia de género y violencia doméstica, cit., págs. 62-63.

${ }^{53}$ RAMÓN RIBAS, ibídem.

54 OLMEDO CARDENETE, El delito de violencia habitual en el ámbito doméstico: análisis teórico y jurisprudencial, Barcelona, 2001, pág. 64.

55 De modo similar, FELIP SABORIT/RAGUÉS i VALLÈS, Lecciones de Derecho penal. Parte Especial, Silva SÁNCHEZ (director), Barcelona 2006, pág. 102, afirman que "finalmente se ha impuesto entre la doctrina y la jurisprudencia la idea de que lo decisivo no es el numero de agresiones probadas individualmente consideradas, sino la existencia de un estado o clima de violencia permanente. Por tanto, la existencia de brotes agudos de violencia es simplemente indicio del clima de hostilidad y hostigamiento crónico"; MENDOZA CALDERÓN, "Hacia un Derecho penal sin fundamentación material del injusto....", cit., pág. 13, afirma que se penaliza "...por ese estado de violencia permanente en el que vive el sujeto pasivo que implica una mayor gravedad de los hechos y la afección a un bien jurídico distinto de la salud, la integridad moral".
} 
En definitiva, como afirma MARÍN DE ESPINOSA CEBALLOS ${ }^{56}$ "el delito de violencia familiar pretende castigar el trato degradante infligido al familiar, que le hacen perder la consideración de persona para ser reducida a la condición de mera cosa, pudiendo provocarle una grave bumillación o vejación".

Esta línea argumental de que el fundamento de la regulación de la violencia familiar en el ámbito doméstico se encontraba precisamente en el clima de violencia, temor y degradación generado con la reiteración de los comportamientos por parte del sujeto activo, también fue mantenida en la jurisprudencia. Así, por centrarnos en la jurisprudencia más reciente, el Tribunal Supremo afirma en su Sentencia de 5 de Octubre de 2005 que:

“...con las conductas que integran el delito de violencia doméstica se viene a crear, por su repetición, una atmósfera irrespirable o un clima sistemático de maltrato, no sólo por lo que comporta de ataque a la integridad física o psíquica de las víctimas sino, esencialmente, por lo que implica de vulneración de los deberes especiales de respeto entre las personas unidas por tales vínculos y por la nefasta incidencia en el desarrollo de los menores que están formándose y creciendo en ese ambiente familiar. (...) La violencia física o psíquica habitual a que se refiere el artículo 173 es algo distinto de los concretos actos de violencia, aisladamente considerados y el bien jurídico protegido es mucho más amplio y relevante que el mero ataque a la integridad, quedando afectados fundamentales valores de la persona y especialmente la integridad moral de las víctimas (...) (Fundamento Jurídico Primero)" ${ }^{57}$.

De forma similar, la Sentencia de 1 de Junio de 2006, rechazando el automatismo numérico a la hora de apreciar la habitualidad requerida por el delito, mantiene que:

...lo relevante para apreciar la habitualidad, más que la pluralidad en sí misma, es la repetición o frecuencia que suponga una permanencia en el trato violento, siendo lo importante que el Tribunal llegue a la convicción de que la víctima vive en un estado de agresión. En esta permanencia radica el mayor desvalor que justifica una tipificación autónoma por la presencia de una gravedad mayor que la que resultaría de la mera agregación de las desvaloraciones propias de cada acción individual.

Es decir, lo relevante para la aplicación del tipo de maltrato no es la reiteración documentada de una conducta, sino la creación de un espacio de terror por parte del sujeto activo mediante la

\footnotetext{
${ }^{56}$ Cfrs. MARÍN ESPINOSA CEBALLOS, La violencia doméstica, cit., pág. 192.

${ }^{57}$ En este mismo sentido, vid. Sentencias del Tribunal Supremo de 7 de Septiembre de 2000, 24 de Junio de 2000 y 10 de Enero de 2002.
} 
Núñez Castaño - La violencia doméstica en la legislación española...

reiteración de conductas violentas tendentes a degradar al sujeto pasivo que las recibe. (Fundamento Jurídico Tercero) ${ }^{58}$.

Muy descriptiva en esta materia resulta la Sentencia del Tribunal Supremo de 14 de Febrero de 2007 donde afirma que la conducta típica del art. 173.2 viene integrada por una forma de actuar y de comportarse de manera habitual en la que la violencia está constantemente presente, creando una situación permanente de dominación sobre las víctimas, que las atemoriza impidiéndoles el libre desarrollo de su vida. Tal forma de actuar se traduce y manifiesta en distintos actos agresivos, de mayor o menor entidad, pero siempre encuadrados en aquel marco de comportamiento.

Del mismo modo, la Fiscalía General del Estado, ya desde la Circular 1/1998 de 24 de Octubre afirma que el bien jurídico protegido en este delito es, aunque entre otros, la integridad moral. Llegando a afirmar en la Circular 4/2003, de 30 de Diciembre que la esencia del delito de maltrato habitual se sustenta en "la prueba de la creación de un «clima de temor» en las relaciones familiares, más que en la constatación de un determinado numero de actos violentos" $\$ 59$.

Consecuentemente, si tal como hemos puesto de relieve en los anteriores planteamientos, lo esencial, lo realmente relevante en el delito de violencia habitual en el ámbito doméstico, es el entorno de violencia, el clima de temor o situación de angustia que provocan una atmósfera degradante y humillante para la persona que la sufre, independientemente de la sucesión de actos individuales que la vayan provocando, entiendo que es precisamente la integridad moral lo que aquí se pretende proteger. Y ello, porque este tipo de comportamientos, tanto por lo reiterados como por la especial relación que une a los sujetos de los mismos, generan graves sentimientos de humillación y degradación, de reducción a una condición inferior a la de persona, característicos de los atentados contra la integridad moral.

En definitiva, el art. 173, tanto en su número primero como en el segundo, regula conductas que menoscaban gravemente la integridad moral, es decir, que "bumillen, degraden, envilezcan y, en definitiva, instrumentalicen al sujeto que lo padece, utilizándolo como cosa y no como fin en si mismo considerado ",60. Por tanto, siendo el bien jurídico que se protege el mismo, la regulación autónoma y diferenciada de ambos tipos delictivos tiene que encontrar su justificación en los comportamientos realizados, esto es, en la conducta típica que se describe en el texto penal.

\footnotetext{
${ }^{58}$ En este sentido, vid. Sentencias del Tribunal Supremo de 23 de Mayo y de 10 de Julio de 2006

${ }^{59}$ En la misma línea, vid. Circular 4/2005, de 18 de Julio, de la Fiscalía General del Estado, relativa a los criterios de aplicación de la Ley Orgánica de medidas de protección integral contra la Violencia de Género.

${ }^{60}$ Cfrs. PÉREZ MACHIO, "Concepto jurídico de «mobbing», bien jurídico lesionado y su tutela jurídico-penal”, Revista Electrónica de Derecho Penal y Criminología, no 6, 2004, pág. 51, http://criminet.ugr.es/recpc, 06-06 (2004), consultada el 25 de Octubre de 2008.
} 
REJ - Revista de Estudios de la Justicia - No 12 - Año 2010

\section{La conducta típica del delito de Violencia doméstica habitual}

Las argumentaciones que acabamos de exponer, junto con el cambio de ubicación sistemática del delito de violencia habitual en el ámbito doméstico, determinan la necesidad de constatar la vulneración efectiva de la integridad moral de los sujetos implicados para poder aplicar el mismo a las conductas realizadas. Se trata, por tanto, de establecer que determinadas conductas de violencia entre un círculo restringido de sujetos atentan contra el derecho que tiene toda persona de recibir un trato acorde con su condición de ser humano libre y digno, y de ver respetadas su personalidad y voluntad, no siendo degradado a una condición inferior a la de persona; y en este punto, resulta innegable que un elevado porcentaje de situaciones de violencia doméstica suponen un auténtico atentado contra la integridad moral.

El problema radica ahora en delimitar qué conductas concretas son las que implican ese atentado contra la integridad moral en virtud de lo establecido por el art. 173.2 del Código penal, y en determinar cuál es la diferencia con los comportamientos recogidos en el número primero del mismo precepto a fin de encontrar una justificación a la regulación autónoma e independiente de los mismos.

\section{La conducta típica del número $2^{\circ}$ del art. 173}

La conducta típica regulada en el número segundo del art. 173 del Código penal consiste en "ejercer habitualmente violencia física o psíquica". Se trata, por tanto, de establecer qué debe entenderse por ejercer violencia física o psíquica, y qué relevancia tiene el término "babitualmente" en la descripción típica realizada.

Por lo que se refiere a la violencia física existe un amplio acuerdo doctrinal en considerar que se trata de la aplicación de una fuerza física o acometimiento material sobre el cuerpo del agredido ${ }^{61}$, o "actos de acometimiento físico sobre el cuerpo del sujeto pasivo que inciden directamente sobre su integridad fisica, ${ }^{\text {, }}$. En definitiva, considero que la violencia física debe ser entendida como cualquier manifestación agresiva o de maltrato (golpes, contusiones, zarandeos, empujones bruscos, bofetadas, patadas, etc. $)^{63}$, cualquiera que sea su gravedad. Se trata de un ataque claro que

${ }^{61}$ MUÑOZ SÁNCHEZ, "El delito de violencia doméstica habitual”, en La reforma penal en torno a la violencia doméstica y de género, Boldova Pasamar/Rueda Martín (coords.), Barcelona 2006, pág. 88; MARÍN DE ESPINOSA CEBALLO, El delito de violencia doméstica, cit., pág. 202; GRACIA MARTIN, en Gracia Martín/ Diez Ripollés (coords.), Comentarios al Código penal. Parte especial, Tomo I, Valencia 1997, pág. 452; OLMEDO CARDENETE, El delito de violencia babitual, cit., pág. 79.

${ }^{62}$ GARCÍA ÁLVAREZ/DEL CARPIO DELGADO, El delito de malos tratos en el ámbito familiar, Valencia 2000, pág. 32.

${ }^{63}$ CUENCA I GARCÍA, "La violencia habitual en el ámbito familiar", Revista Jurídica de Cataluña, 1998, pág. 651; DE VEGA RUIZ, Las agresiones familiares en la violencia doméstica, Pamplona 1999, pág. 173; OLMEDO CARDENETE, El delito de violencia habitual, cit., págs. 78-79 quien entiende que pueden incluirse "los golpes en general, las bofetadas y patadas a la víctima, puñetazos, rodillazos, 
Núñez Castaño - La violencia doméstica en la legislación española...

puede ser hasta, incluso, disimulado, pero ha de ser siempre violencia física que no tiene por qué dejar señales físicas de clase alguna (hematomas, heridas, sangre, etc. $)^{64}$.

Pero la delimitación de la conducta típica del número segundo del art. 173 del Código penal no se queda restringida a la violencia física; por el contrario, respondiendo a una importante demanda doctrinal ${ }^{65}$, política y social, la Ley 14/1999 accede, definitivamente a la inclusión, en el anterior artículo 153 del Código penal, actual artículo 173.2, de la violencia psíquica como alternativa y acumulada a la física.

Esta inclusión de la violencia psíquica como modalidad típica del art. 173.2, no estuvo exenta de problemas. El hecho de encontrarnos ante un término nuevo, sin referente alguno en nuestra legislación hasta ese momento ${ }^{66}$, que tiene un carácter impreciso ${ }^{67}$ ha determinado que la doctrina adoptara una actitud cautelosa frente a su admisión, dado que la diversidad de manifestaciones de la violencia psíquica iba a implicar un difícil deslinde entre los comportamientos que debieran constituir infracciones penales, y aquellos otros que simplemente fueran el reflejo de un grave deterioro de la convivencia familiar y que no tienen relevancia penal suficiente $^{68}$.

empujones, tirones de pelo, lanzamientos de objetos contundentes, manotazos y pellizcos dados a un bebé que le causen distintos hematomas, la conducta consistente en zarandear a la víctima, en agarrarla por el cuello, en fustigarla con un látigo o correa, en propinarle un cabezazo o producirle impedimentos temporales de la respiración"; MUNOZ SÁNCHEZ, "El delito de violencia doméstica habitual", cit., pág. 88 afirma que "el acometimiento al cuerpo del agredido puede consistir también en impedirle abandonar el domicilio o en agresiones sexuales".

64 NÚÑEZ CASTAÑO, El delito de malos tratos en el ámbito familiar, cit., pág. 119 y 120.

${ }^{65}$ CUELLO CONTRERAS, El delito de violencia habitual, cit., pág. 32; DEL ROSAL BLASCO, El tipo de violencias, cit., pág. 370; DE VEGA RUIZ, Las agresiones familiares, cit., pág. 172; RUIZ VADILLO, Algunas breves y provisionales consideraciones, cit., pág. 24. Y, principalmente, CUENCA SÁNCHEZ, El nuevo art. 425 del Código penal, cit., pág. 1186, donde afirma que "los castigos psiquicos pueden resultar más perjudiciales o dolorosos para las víctimas y que no existe motivo alguno para privilegiar el refinamiento en los modos de infligir el mal, como sucede en este delito", a la vez que propone determinados ejemplos de violencia psíquica no protegidos por el antiguo art. 425 del Código penal, como privaciones injustificadas de bienes, castigos innecesarios o inmotivados que no se infieran físicamente, actitudes despóticas o de abuso de superioridad del cónyuge o padre que provoquen situaciones vejatorias. También se había pronunciado a favor de su inclusión la Fiscalía General del Estado en su Circular 2/1990. En contra de la inclusión se pronunció DOLZ LAGOS, "Violencia doméstica habitual: mitos y realidades", La Ley, 2000, págs. 1779-1780.

${ }^{66}$ Así, CORTÉS BECHIARELLI, El delito de malos tratos familiares, cit., pág.. 49, afirma que estamos ante un término "absolutamente desconocido".

${ }^{67}$ MUÑOZ SÁNCHEZ, El delito de violencia doméstica habitual, cit., pág. 89.

68 Así, GARCÍA ÁLVAREZ/DEL CARPIO DELGADO, "El delito de malos tratos en el ámbito familiar", cit., págs. 32-34 exigen cierto paralelismo con las violencias físicas, considerando que ambas deben ser actos de acometimiento; DEL MORAL GARCÍA, "El delito de violencia habitual en el ámbito familiar", en Delitos contra las personas, Manuales de formación continuada, Consejo General del Poder Judicial, Madrid 1999, pág. 320, afirma que la interpretación de la expresión violencia psíquica "ha de buscar un equilibrio entre una amplitud desmesurada, que produjese una panjudicialización, convirtiendo en diligencias previas, por maltrato habitual, toda la vida familiar con cierta reiteración de discusiones o 
Desde este planteamiento, entiendo que violencia psíquica se refiere a cualquier acto de acometimiento verbal o de obra, siempre que no implique un contacto corporal directo con el sujeto pasivo, y que recaiga sobre la psiquis del afectado $^{69}$, que de manera más o menos relevante determine la creación de un estado de agresión permanente que pueda suponer un ataque a la integridad moral de la persona ${ }^{70}$.

Así, la violencia psíquica a la que nos estamos refiriendo abarca un amplio abanico de modalidades comisivas, sin que, en principio sea posible dar una definición concreta de la misma, pero pudiendo entenderse que abarcaría todos aquellos comportamientos violentos que no impliquen un contacto corporal directo con la víctima, independientemente de su entidad ${ }^{71}$, y por otro lado, quedarían excluidos todos aquellos supuestos que no representen el más mínimo peligro para el bien jurídico que se protege, esto es, la integridad moral.

Y, en mi opinión, aquí está el principal referente a la hora de delimitar cuales son las conductas típicas que configurar el delito recogido en el art. 173.2 del Código penal. Partiendo de la base de que el cambio de ubicación sistemática realizado por la Ley Orgánica 14/1999, colocó el delito de violencia habitual en el ámbito doméstico en el Título dedicado a la integridad moral, nos vemos obligados a interpretar las conductas típicas reguladas como ataques encaminados a lesionar la integridad moral, o dicho de otro modo, será aplicable el delito de violencia habitual contenido en el art. 173.2 del Cp a aquellos actos de violencia

disputas; o una interpretación tan restrictiva que exigiese la producción de resultados lesivos y que casi redujese a la nada la ampliación del tipo". En esta misma línea, TAMARIT SUMALLA, en Quintero Olivares y otros, Comentarios al Código penal de 1995, Pamplona 1996, pág. 752 propone un interpretación restrictiva de lo que ha de entenderse por violencia psíquica, de tal modo que los efectos derivados de su ejercicio sean equiparables en cuanto a su gravedad a los que trae consigo el ejercicio de la violencia física.

69 NÚÑEZ CASTAÑO, El delito de malos tratos en el ámbito familiar, cit., págs. 121-122.

${ }^{70}$ Hay que partir de la base que el cambio de ubicación sistemática determina al mismo tiempo un cambio en los parámetros de interpretación del tipo delictivo que estamos analizando, de forma que entiendo que ya no es posible afirmar que la violencia psíquica a la que se refiere el art. 173.2 del Código penal, debe reflejarse en, al menos, una puesta en peligro para la salud mental tal como se afirmaba en relación con el anterior art. 153; sino que lo determinante en este momento, es que el comportamiento violento del sujeto activo mediante expresiones verbales o de obra (que no supongan un contacto corporal directo con la víctima), pueda implicar, fundamentalmente por su repetición como veremos posteriormente, la producción de un clima de miedo, de angustia, de humillación, que se refleje en un sentimiento de inferioridad y de degradación de quien las recibe, y que determinen un ataque a la integridad moral.

${ }^{71}$ En este sentido, GONZÁLEZ RUS, “Tratamiento penal de la violencia sobre personas ligadas al autor por relaciones familiares, afectivas o legales, después de la L.O. 14/1999, de 9 de Junio”, en Revista Jurídica de Andalucía, no 30, 2000, pág. 19, considera que son modalidades de violencia psíquica "la coacción moral, la amenaza, la intimidación, la presión psicológica que atemoriza y perturba la tranquilidad y seguridad de la víctima. Igualmente las humillaciones, vejaciones, insultos y menosprecios, a caballo entre las ofensas al honor y la dignidad persona y la verdadera intimidación...”. 
Núñez Castaño - La violencia doméstica en la legislación española...

física o psíquica que impliquen un ataque a la integridad moral de la persona a la que van dirigidos ${ }^{72}$.

Y la pregunta en este punto es evidente: ¿todos los actos de violencia, fuerza o acometimiento físico $\mathrm{y} / \mathrm{o}$ psíquico, fundamentalmente estos últimos, determinan un atentado a la integridad moral de la persona? Es decir, y refiriéndonos especialmente a la violencia psíquica, ¿los insultos o vejaciones provocados por una discusión esporádica en el seno familiar determinaría la existencia de un ataque contra la integridad moral?

$\mathrm{Si}$ consideramos que atentan a la integridad moral todos aquellos comportamientos que humillen, degraden, envilezcan $y$, en definitiva, instrumentalicen al sujeto que los padece, utilizándolo como cosa y reduciéndolo a una condición inferior a la de persona, resulta notorio que los insultos o humillaciones realizadas en el curso de una discusión aislada y esporádica no determinan este resultado. Pero, ¿tampoco lo determinan esos mismos insultos, vejaciones, humillaciones, amenazas realizados habitualmente durante un periodo prolongado de tiempo? Puede que las conductas realizadas, esto es, los insultos o las amenazas vertidas sean esencialmente las mismas, pero el resultado que provoca la constante repetición, obviamente no es el mismo.

En este punto es donde adquiere relevancia el segundo de los elementos que configuran la conducta típica descrita en el art. 173.2 del Código penal, esto es, la habitualidad, que dichos comportamientos se realicen habitualmente, que se constituye en el elemento vertebrador del tipo que fundamenta su desvalor particular y justifica su tipificación autónoma ${ }^{73}$. Como veremos, considero que es precisamente este elemento el que da sentido a la criminalización de este tipo de comportamientos, distinto es si la forma en la que se ha realizado es la adecuada o no.

\footnotetext{
${ }^{72}$ En mi opinión, este cambio de ubicación sistemática ha determinado que hayan dejado de tener sentido alguna de las polémicas que se habían planteado en relación con la redacción del delito de violencia habitual en el ámbito doméstico cuando se hallaba incardinado en sede de los delitos de lesiones. Así, considero que ya no es posible considerar que nos encontremos ante un delito de peligro, sino ante un delito de resultado, porque es preciso que los actos violentos realizados determinen el menoscabo o ataque a la integridad moral. En este mismo sentido, MUÑZ SÁNCHEZ, EL delito de violencia doméstica habitual, cit., pág. 87 que afirma que "la acción viene dada por la violencia física o psíquica y el resultado material por la situación de agresión permanente a la que da lugar"; MARÍN DE ESPINOSA CEBALLOS, "La violencia doméstica", cit., pág. 217, mantiene que el atentado a la integridad moral es el resultado que provoca el ejercicio de violencia física o psíquica de manera reiterada sobre la víctima; OLMEDO CARDENETE, "El delito de violencia habitual", cit., págs. 63-64.

73 NÚÑEZ CASTAÑO, El delito de malos tratos en el ámbito familiar, cit., pág. 145; OLMEDO CARDENETE, El delito de violencia habitual en el ámbito doméstico, cit., pág. 41; GARCÍA ÁLVAREZ/DEL CARPIO DELGADO, El delito de malos tratos, cit., pág. 65.
} 
A efectos de determinar qué debe entenderse por esta habitualidad, y para evitar la polémica doctrinal que se había generado hasta entonces ${ }^{74}$, la Ley Orgánica 14/1999 introdujo un segundo párrafo en el art. 153, actual art. 173.3 del Código penal, en el que se contenía lo que a efectos legales debiera entenderse por habitualidad. Sin embargo, lo cierto es que esta regulación legislativa no consiguió terminar con la polémica respecto de lo que debiera entenderse por habitualidad. Mientras un sector de la doctrina consideraba que lo que contiene el actual art. 173.3 es una definición legal de habitualidad ${ }^{75}$, otra parte de la doctrina entendía que se limitaba a establecer una serie de criterios legales que necesariamente habría que tener en cuenta para constatar la existencia de habitualidad en el comportamiento realizado ${ }^{76}$.

Sin entrar en mayores consideraciones a este respecto, considero que lo que aporta el art. 173.3 del Código penal es un concepto fáctico ${ }^{77}$ donde lo realmente relevante radica en que la afección al bien jurídico se produce por la reiteración de actos de violencia que dan lugar a un estado de agresión permanente o a un clima de violencia dentro de un determinado entorno ${ }^{78}$.

Otra interpretación se derivaría de una concepción subjetiva de la habitualidad, donde lo relevante no sería la repetición de los actos violentos, sino que las situaciones violentas fueran expresión de que el sujeto se ha formado un hábito, inclinación o tendencia a su realización, configurando el tipo contenido en el art. 173.2 del Código penal como un delito habitual o de hábito ${ }^{79}$, donde lo

\footnotetext{
${ }^{74}$ En relación con la polémica suscitada, vid. NÚÑEZ CASTAÑO, El delito de malos tratos en el ámbito familiar, cit., págs. 147 a 168 y la bibliografía allí citada.

75 ACALE SÁNCHEZ, El delito de malos tratos físicos y psíquicos, cit., pág. 111; CORTÉS BECHIARELLI, El delito de malos tratos familiares, cit., pág. 71, aunque afirma categóricamente que se trata de una definición hueca e indeterminada que no define nada; MUÑOZ CONDE, Derecho penal, parte especial, $15^{a}$ ed., Valencia 2004, pág. 189; GÓMEZ RIVERO, “Algunos aspectos del delito de malos tratos", cit., , pág. 70; MAQUEDA ABREU, "La violencia habitual en el ámbito familiar: razones de una reforma", en El nuevo Código penal español. Estudios penales en memoria del Profesor José Manuel Valle Muñiz, Quintero Olivares/Morales Prats (direct.), Pamplona, 2001, pág. 1520; MARÍN DE ESPINOSA CEBALLOS, La violencia doméstica, cit., pág. 222.

76 MUÑOZ SÁNCHEZ, "El delito de violencia doméstica habitual”, cit., pág. 92; OLMEDO CARDENETE, El delito de violencia habitual en el ámbito doméstico, cit., pág. 91.

77 Así, MUÑOZ CONDE, Derecho penal, Parte Especial, 15ª ed., cit., pág. 189; DEL MORAL GARCÍA, "El delito de violencia habitual en el ámbito familiar", cit., pág. 324; MUÑOZ SÁNCHEZ, "El delito de violencia doméstica habitual....", cit., pág. 92. En un sentido similar, pero con la denominación de "criminológico", vid. Sentencias del Tribunal Supremo de 22 de Enero de 2002 y de 24 de Junio de 2000; mientras que la Circular 2/1990 de la Fiscalía General del Estado, de 17 de Octubre, se refiere a este concepto como "naturalístico".

78 Cfrs. MUÑOZ CONDE, Derecho penal. Parte especial, $15^{a}$ ed., cit., págs. 188 y ss..; MARÍN DE ESPINOSA CEBALLOS, La violencia doméstica, cit., pág. 222-227; MUÑOZ SÁNCHEZ, "El delito de violencia doméstica habitual", cit., pág. 91.

${ }^{79}$ Esta concepción subjetiva ha sido mantenida por GRACIA MARTIN, Comentarios al Código penal, Parte especial, I, 1997, Art. 153, marginales 93-98; GONZÁLEZ RUS, "Violencia habitual sobre personas ligadas al agresor por relaciones familiares, afectivas o legales", en Addenda al Curso de
} 
Núñez Castaño - La violencia doméstica en la legislación española...

relevante es que se pueda acreditar este hábito o tendencia en el autor. Al margen de que no existe base legal para realizar la anterior interpretación, en este punto considero imprescindible hacer constar que lo habitual a lo que se refiere el art. 173 del Código penal es la conducta agresiva, el comportamiento violento, y no el agresor; un planteamiento inverso nos devolvería a épocas pretéritas, en las que la personalidad o la forma de vida del sujeto constituían la esencia del reproche penal. En un Estado democrático de derecho como el nuestro, un Derecho penal de autor resulta de todo punto inadmisible ${ }^{80}$.

Se trata, por tanto, de determinar cuáles son los criterios que establece el art. 173.3 del Código penal para poder apreciar la habitualidad a la que se refiere el número segundo del mismo artículo. Y en este sentido considero que son dos los aspectos a tener en cuenta a fin de poder acreditar la existencia de ese clima de violencia o de agresión permanente: la existencia de sucesivos actos de violencia y una cierta proximidad y prolongación temporal.

En el momento actual, la discusión sobre el número de actos concretos de violencia que tengan que resultar acreditados ha perdido parte de su sentido, principalmente debido al cambio de ubicación sistemática del delito de violencia habitual; cambio que determina que el núcleo esencial del atentado contra la integridad moral en este tipo de comportamientos se centra en la existencia de una situación permanente de violencia, que provoque un sentimiento de humillación e inferioridad de los sujetos que la padecen.

De este modo, se prescinde del "automatismo numérico", por entender que lo relevante para la habitualidad no es el número de actos violentos que se realicen, sino la repetición y frecuencia de los mismos, que determina la permanencia del trato violento y la convicción de que la víctima vive en un estado de agresión permanente. Ello supone la existencia de un trato degradante para la víctima, que le produce un sentimiento constante de angustia, temor, humillación e inferioridad ${ }^{81}$.

\footnotetext{
Derecho penal español, Parte especial, 1999, pág. 18. Esta misma línea ha sido recogida por el Tribunal Supremo, en las Sentencias de 29 de Junio de 2000, 27 de Enero de 2002 y de 16 de Mayo de 2002 que señalan que "los actos violentos sólo tienen el valor de acreditar la actitud del agresor".

${ }^{80}$ Cfrs. NÚÑEZ CASTAÑO, El delito de malos tratos en el ámbito familiar, cit., pág. 162; CORTÉS BECHIARELLI, El delito de malos tratos familiares, cit., pág. 81; OLMEDO CARDENETE, El delito de violencia habitual en el ámbito doméstico, cit., pág. 100; MARÍN DE ESPINOSA CEBALLOS, La violencia doméstica, cit., pág. 232; MUÑOZ SÁNCHEZ, "EL delito de violencia doméstica habitual", cit., pág. 92.

${ }^{81}$ Cfrs. en este sentido, MAQUEDA ABREU, "La violencia habitual en el ámbito familiar: razones de una reforma", cit., pág. 1522; OLMEDO CARDENETE, El delito de violencia habitual en el ámbito doméstico, cit., págs. 91 y ss.; MARÍN DE ESPINOSA CEBALLOS, La violencia doméstica, cit., pág. 230: MUÑOZ SÁNCHEZ, "El delito de violencia habitual”, cit., pág. 94.
} 
Sobre esta base, tal como afirma OLMEDO CARDENETE ${ }^{82}$, "la cuantificación numérica es importante, pero no suficiente y el problema interpretativo no se soluciona fijando una cifra. Hay que atender a la situación, al contexto, a la persistencia del clima enrarecido de convivencia generado por esos episodios de violencia reiterados que, aunque sean espaciados, están presentes de una forma latente en todo momento ${ }^{983}$.

Este planteamiento se recoge en la Sentencia del Tribunal Supremo de 7 de Julio de 2000, en la que se afirma que:

La habitualidad que necesariamente debe darse en el ejercicio de la violencia física dentro del ámbito de las relaciones familiares para integrar el delito autónomo del art. $153 \mathrm{CP}$ y antes el $425 \mathrm{CP}$ de 1973 es una exigencia típica un tanto imprecisa que ha originado distintas corrientes interpretativas. La más habitual entiende que tales exigencias se satisfacen a partir de la tercera acción violenta; criterio que no tiene más apoyo que la analógica aplicación del concepto habitualidad que el artículo $94 \mathrm{CP}$ establece a los efectos de suspensión y sustitución de penas. Otra línea interpretativa prescindiendo del automatismo numérico anterior, ha entendido con mayor acierto que lo relevante para apreciar la habitualidad, más que la pluralidad en sí misma, es la repetición o frecuencia que suponga una permanencia en el trato violento siendo lo importante que el Tribunal llegue a la convicción de que la víctima vive en un estado de agresión permanente. En esta permanencia radica el mayor desvalor que justifica una tipificación autónoma por la presencia de una gravedad mayor que la que resultaría de la mera agregación de las desvaloraciones propias de cada acción individual $(\ldots)^{84}$.

Sobre esta base, considero que lo realmente relevante a los efectos de determinar la existencia de la habitualidad radica en la acreditación de la existencia de una clima de violencia, de una atmósfera irrespirable de angustia y de miedo, de tal modo que el número de actos violentos concretos que se hayan producido deja de ser concebido como un criterio constitutivo de la habitualidad para ser considerado como un mero indicador de la misma. Es más, en mi opinión no puede deducirse otra cosa de la regulación del art. 173.3 del Código penal, cuando al delimitar lo que debe considerarse habitualidad a los efectos de este tipo

\footnotetext{
82 Cfrs. OLMEDO CARDENETE, El delito de violencia habitual en el ámbito doméstico, cit., pág. 94.

${ }^{83}$ En el mismo sentido, DEL MORAL GARCÍA, "El delito de violencia en el ámbito familiar", cit., pág. 325; GARCÍA ÁLVAREZ/DEL CARPIO DELGADO, EL delito de malos tratos en el ámbito familiar, cit., págs. 67-68; MAQUEDA ABREU, "La violencia habitual en el ámbito familiar", cit., pág. 1529.

${ }^{84}$ En la Sentencia mencionada, que supone un punto de inflexión respecto a la determinación de la habitualidad mediante la acreditación de tres o más actos de violencia, se entiende que sería suficiente con la prueba de tan solo dos agresiones si con ellas se evidencia el estado de agresión permanente en que se desenvuelve la víctima.
} 
Núñez Castaño - La violencia doméstica en la legislación española...

delictivo, establece que se atenderá a los actos de violencia acreditados “...con independencia de que dicha violencia se haya ejercido sobre la misma o diferentes víctimas de las comprendidas en este artículo". Esta afirmación demuestra claramente que lo que se castiga en este precepto no son los actos de violencia concretos realizados, incluso de manera reiterada, ya que para ello habría que referirse a una única víctima de los mismos; por el contrario, la ratio criminis de este tipo de comportamientos es precisamente el clima general de violencia, de angustia y de temor que se genera dentro de un determinado ámbito de relaciones.

Sobre esta base, no es preciso que se determine de manera exacta y detallada el cómo y el cuándo de cada uno de los actos violentos concretos que se hayan producido, sino que es suficiente con que, mediante cualquier medio de prueba que permita acreditarlos ${ }^{85}$, se determine la gravedad, efectos y dinámica del comportamiento dentro de una mínima delimitación temporal ${ }^{86}$; esto es, el acaecimiento sucesivo de hechos violentos por parte del agresor que pone de relieve que no son meramente ocasionales o circunstanciales y que forman parte de un comportamiento sistemático que ha deteriorado sensiblemente la confianza, personalidad y autoestima de la víctima ${ }^{87}$, provocándole un sentimiento de humillación e inferioridad.

Este planteamiento ya fue establecido en la Circular 1/1998 de la Fiscalía General del Estado al afirmar que:

Los actos aislados de violencia que integran la nota de habitualidad no es preciso que sean idénticos: cabe considerar, para aunarlos, desde los más leves (v. gr. La falta de maltrato de obra del art. 617.2) hasta los más graves, para apreciar, desde el punto de vista de su producción repetida en el tiempo, la existencia de la habitualidad, como conducta reiterada distinta de cada uno de tales actos pero evidenciada por éstos, que, más o menos graves, son desplegados por el sujeto activo respecto de las personas del entorno familiar y que propician no una situación puntual o hecho aislado violento sino la creación de un clima de violencia sostenida en dicho núcleo familiar que el legislador pretende reprimir, además o junto a tales manifestaciones (...)

(...) La conducta del art. 153 (actual art. 173.2) -violencia habitual- es distinta de la de los concretos actos aislados en que se manifiesta. Los actos aislados se cometen en un determinado momento y producen un concreto resultado. La violencia habitual

\footnotetext{
85 Vid. en este sentido la Sentencia de la Audiencia Provincial de Barcelona de 20 de Mayo de 1999.

${ }^{86}$ Cfrs. OLMEDO CARDENETE, El delito de violencia habitual en el ámbito doméstico, cit., págs. 104 y 105; CORTÉS BECHIARELLI, El delito de malos tratos...., cit., pág. 82.

${ }^{87}$ Cfrs. OLMEDO CARDENETE, El delito de violencia habitual en el ámbito doméstico, cit., págs. 107 y 108.
} 
es una actividad permanente que no cabe señalar cometida en momentos concretos sino que, aunque se manifieste en actos susceptibles de ser singularizados, se despliega durante todo el tiempo y también en el lapso de tiempo que media entre los concretos actos de violencia. (...) La violencia habitual es algo más que la mera suma de los actos en que se manifiesta (...)

Más categórica a este respecto es la Sentencia del Tribunal Supremo no 613/2006 de 1 de Junio donde se afirma que lo relevante para la aplicación del delito de violencia de género no es la reiteración documentada de una conducta, sino la creación de un espacio de terror por parte del sujeto activo mediante la reiteración de conductas violentas tendentes a degradar al sujeto pasivo que las recibe.

Efectivamente, considero que la conducta descrita en el art. 173.2 del Código penal debe interpretarse de manera conjunta, es decir, que el comportamiento realmente prohibido es aquél que sea idóneo para vulnerar el bien jurídico que se protege, tal como hemos señalado, la integridad moral, y este bien jurídico no se lesiona por la mera suma de actos violentos concretos, sino por la creación de un clima de violencia y angustia provocado por esa reiteración, que desemboca en un sentimiento de miedo, humillación e inferioridad de la o las víctimas del mismo.

Una vez delimitada, de forma genérica, qué conductas son las que configuran el delito recogido en el art. 173.2 del Código penal, nos queda por determinar cuál es la diferencia entre este número segundo del art. 173 y el número primero del mismo precepto a fin de poder justificar o no la razón de su tipificación autónoma.

\section{La conducta típica del $\mathrm{n}^{\circ} 1$ del art. 173 del Código penal}

El número primero del art. 173 del Código penal castiga a quien "infligiere a otra persona un trato degradante menoscabando gravemente su integridad moral". De este modo, el legislador deja sin definir lo que entienda por trato degradante, situación que va a provocar una discusión doctrinal al respecto, llegando a afirmar un sector doctrinal que se trata de un tipo penal "absolutamente abierto" y claramente contrario al principio de legalidad ${ }^{88}$.

Se trata de determinar por tanto, qué debe entenderse por trato degradante, y para ello considero necesario realizar algunas precisiones al respecto. En primer lugar, como expondré a continuación, entiendo que el trato degradante en sí mismo no constituye una modalidad de la acción, sino el resultado que la acción

\footnotetext{
${ }^{88}$ Cfrs. CARBONELL MATEU/GONZÁLEZ CUSSAC, en Vives Antón y otros, Comentarios al Código penal de 1995, vol. I, Valencia 1996, pág. 896; DE LA CUESTA ARZAMENDI, "Tortura y otros atentados contra la integridad moral”, en Estudios Penales y Criminológicos, XXI, 1998, pág. 79.
} 
Núñez Castaño - La violencia doméstica en la legislación española...

provoca, y en segundo lugar que, como veremos, por definición de las normativas internacionales, no existe un trato degradante que no suponga un menoscabo grave de la integridad moral. Es decir, la alusión que hace el legislador a la necesidad de que provoque un grave menoscabo de la integridad moral, pudiera resultar superflua por cuando es inherente al propio concepto de trato degradante ${ }^{89}$.

A mi juicio, la acción no tiene modalidades limitadas, sino que cabe cualquier forma de realizarla siempre que produzca el resultado de infligir un trato degradante a una persona, es decir, se puede realizar empleando engaño, violencia, intimidación, etc., siempre y cuando produzca ese menoscabo de la integridad moral.

De este modo, el primer paso a dar consiste en determinar qué debe entenderse por trato degradante. Para ello, considero que el punto de partida radicaría en el Art., 15 de nuestra Constitución que prohíbe los tratos degradantes como núcleo esencial del derecho fundamental a la integridad moral. Desde este prisma hay que analizar lo que deba entenderse por trato degradante, y para ello resultan relevantes las precisiones formuladas por el Tribunal Europeo de Derecho Humanos en su Sentencia de 18 de enero de 1978 (caso Irlanda contra Reino Unido ${ }^{90}$ que fueron recogidas por nuestro Tribunal Constitucional en su Sentencia 120/1990, de 27 de Junio, donde afirma que la tortura, tratos inhumanos y tratos degradantes "son nociones graduadas de una misma escala que en todos sus tramos denotan la causación, sean cuales fueren sus fines, de padecimientos físicos o psíquicos ilicitos infligidos de modo vejatorio para quien los sufre (...) y con esa propia intención de vejar y doblegar la voluntad del sujeto paciente" (Fundamento Jurídico no 9) ${ }^{91}$.

Así, el Tribunal Europeo de Derechos Humanos ha establecido en la Sentencia de 18 de Enero de 1978 (caso Irlanda contra Reino Unido) que se tratos degradantes son aquellos que "pueden crear en las víctimas sentimientos de temor, de angustia y de inferioridad, susceptibles de bumillarles, de envilecerles y de quebrantar en su caso su resistencia física y moral". De este modo, lo que caracteriza este concepto no es el grado de dolor o sufrimiento, como pasa con la tortura y los tratos inhumanos, sino la humillación y sensación de envilecimiento que provoque la acción en el afectado $^{92}$. Por tanto, para que un trato merezca la calificación de degradante debe

\footnotetext{
89 Cfrs. MUÑOZ SÁNCHEZ, Los delitos contra la integridad moral, cit., pág.40; GONZÁLEZ CUSSAC, "Delitos de torturas y otros tratos degradantes (Delitos contra la integridad moral)", en Estudios sobre el Código penal de 1995, parte Especial, pág. 109.

90 También en la misma línea se pueden citar las Sentencias del mismo Tribunal de 25 de Abril de 1978 (caso Tyren) y de 25 de Febrero de 1982 (caso Campbell y Cosans).

${ }^{91}$ Esta doctrina ha sido reiterada en las Sentencias del Tribunal Constitucional 137/1990, de 19 de Julio, 57/1994 de 28 de febrero y 215/1994, de 14 de Julio.

92 Cfrs. MUÑOZ SÁNCHEZ, Los delitos contra la integridad moral, cit., pág. 36; RAMÓN RIBAS, Violencia de género y violencia doméstica, cit., págs. 63-64.
} 
REJ - Revista de Estudios de la Justicia - No 12 - Año 2010

ocasionar al afectado una humillación o envilecimiento que alcance un mínimo de gravedad $^{93}$.

Todas estas consideraciones jurisprudenciales han dado pie a que la doctrina haga radicar el núcleo del concepto de trato degradante en la provocación de padecimientos físicos o psíquicos vejatorios que provoquen humillación y/o envilecimientos. Así, por ejemplo, MUÑOZ SÁNCHEZ" afirma que “...cabe definir los tratos degradantes como toda situación que, con independencia del medio utilizadoviolencia, intimidación, engaño, etc.-, y de si existe o no doblegamiento de la voluntad de otra persona, conlleva generalmente padecimientos físicos o psíquicos y produce en todo caso un sentimiento de bumillación o sensación de envilecimiento ante los demás o ante sí mismo". Por su parte, DEL ROSAL BLASCO ${ }^{95}$ entiende que "....se causa trato degradante a otra persona cuando se le producen, por acción u omisión, con cualquier fin, padecimientos físicos o psíquicos que de forma grave la vejan, la envilecen o la cosifican, ante sí mismo o ante los demás, produciendo un sentimiento de bumillación,"96.

Determinado el núcleo del concepto de los tratos degradantes, es necesario resaltar que de la redacción del tipo contenido en el número primero del art. 173 del Código penal no se desprende de qué manera o por qué medios se ha de ocasionar ese trato degradante, sino que simplemente establece que ha de producirse una afección grave del bien jurídico que se protege, esto es, la integridad moral. En otras palabras, no existen limitaciones en las modalidades típicas ni en los medios comisivos, de manera que se admite como medio de comisión del delito todo instrumento que sea idóneo para producir el trato degradante $e^{97}$.

\footnotetext{
93 Esta doctrina del Tribunal Europeo de Derecho Humanos en relación con el concepto de tratos degradantes ha sido recogida por nuestro Tribunal Constitucional en reiteradas Sentencias, así: STC 65/1986, de 22 de Mayo, 89/1987, de 3 de Julio, 15/1991 de 21 de Julio y 57/1994, de 28 de Febrero.

${ }^{94}$ Cfrs. MUÑOZ SÁNCHEZ, Los delitos contra la integridad moral, cit., pág. 44.

${ }^{9}$ Cfrs. DEL ROSAL BLASCO, "Torturas y otros delitos contra la integridad moral en el Código penal de 1995", cit., pág. 1234.

${ }_{96}$ En el mismo sentido, MUÑOZ CONDE, Derecho penal, Parte especial, $15^{\text {a }}$ ed., 2004, cit., pág. 185; LÓPEZ GARRIDO/GARCÍA ARÁN, EL Código penal de 1995 y la voluntad del legislador, cit., pág. 106; GONZÁLEZ CUSSAC, "Delitos de tortura y otros tratos degradantes”, cit., pág. 109.

${ }^{97}$ Cfrs. NÚÑEZ CASTAÑO, El delito de malos tratos en el ámbito familiar, cit., pág. 90; DEL ROSAL BLASCO, "Torturas y otros delitos contra la integridad moral en el Código penal de 1995", cit., pág. 1234; GARCÍA ARÁN, "La protección penal de la integridad moral”, en La ciencia del Derecho penal ante el nuevo siglo, Libro Homenaje al Profesor Cerezo Mir, Diez Ripollés/Romeo Casabona/Gracia Martín/Higuera Guimerá (editores), Madrid 2002, pág. 1253; MUÑOZ SÁNCHEZ, Los delitos contra la integridad moral, cit., pág. 46. Sin embargo, parece limitar los medios comisivos del art. 173, OLMEDO CARNEDETE, El delito de violencia habitual en el ámbito doméstico, cit., págs. 44 y 45, al afirmar que la integridad moral se ve menoscabada “...cuando de un modo sistemático y continuado se violenta física y psíquicamente a la víctima (art. 153 )(se está refiriendo a la regulación anterior a la Ley 11/2003, con lo cual la argumentación se traslada al actual art. 173.2), cuando es objeto de humillación o vejación infligiéndole tratos inbumanos o degradantes (art. 173)(obviamente, el art. 173.1 de la regulación actual)...”, de manera que parece hacer radicar la diferencia entre el
} 
Núñez Castaño - La violencia doméstica en la legislación española...

Esta indeterminación de los medios comisivos permite abarcar diversos comportamientos. Así, aquéllos en los que se emplee la violencia física sobre el cuerpo de la víctima, ocasionando un contacto corporal directo que implica el doblegamiento de su voluntad ${ }^{98}$; el empleo de violencia psíquica, mediante comportamientos en los que a través de medios de naturaleza psíquica hacen que la víctima pierda su propia autoestima o se sienta abatida o despreciable, degradada o humillada; también es posible la utilización de medios fraudulentos, es decir, engaño, artificio, mentira con la cual se cree en la víctima una situación de humillación o envilecimiento ${ }^{99}$. En definitiva, la limitación de los medios comisivos en el número 1 del art. 173 del Código penal, no encuentra justificación ni legal ni de política criminal, por lo cual, es factible el empleo de cualquier medio, modo o forma de comisión del delito siempre y cuando éste ocasione un trato degradante y, consecuentemente, un sentimiento de humillación y degradación en la víctima.

Ahora bien, aun no existiendo limitación alguna respecto de las modalidades comisivas del delito contenido en el art. 173.1 del Código penal, sí hay que constatar la necesidad de que el menoscabo a la integridad moral que suponga el trato degradante sea grave. Es cierto que el trato degradante menoscaba gravemente la integridad moral, pero, como afirma GARCÍA ARÁN ${ }^{100}$, "esa gravedad no necesariamente coincide con la que, expresamente ha querido exigir el Código Penal". De manera que la conducta típica regulada en el número primero del art. 173 quedaría restringida a aquellos supuestos de especial gravedad, entre los que claramente considera incluidos esta autora aquellos comportamientos por los que se crea una situación permanente de "cosificación" de la persona, de reducción a objeto disponible por otros ${ }^{101}$.

En definitiva, conducta típica del número primero del art. 173 serían todos aquellos comportamientos, cualquiera que sea su modalidad de comisión, que provocando un trato degradante hacia las personas supongan un grave menoscabo

delito recogido en el actual 173.2 y en contenido en el número primero del mismo precepto exclusivamente en la conducta realizada, en el modo de atentar contra la integridad moral; así, en el caso de la violencia doméstica habitual consistiría en el empleo de violencia física o psíquica, y en el art. 173.1 en provocar un sentimiento de humillación o vejación, infligiéndole tratos inhumanos o degradantes por una vía distinta a la de la violencia. Considero, que esta restricción no encuentra apoyo legal alguno.

${ }^{98}$ En este punto, MUÑOZ SÁNCHEZ, Los delitos contra la integridad moral, cit., pág. 47 afirma que la violencia física mediante la que se realice el trato degradante puede recaer sobre una tercera persona distinta de aquél al que se pretende humillar o envilecer, pero con la que la víctima tiene una cierta relación de afectividad, como puede ser la madre a la que se muestra cómo se maltrata o tortura a su hijo. Sin embargo, entiendo que éste sólo podría ser ejemplo de violencia física como modo comisivo del atentado contra la integridad moral, respecto de quien la sufre directamente, esto es, en el ejemplo mencionado, el hijo; por el contrario, respecto de la madre, lo que se está produciendo es una violencia psíquica, que también sería una forma de comisión del trato degradante, pero de un modo diverso.

${ }^{99}$ Cfrs. MUÑOZ SÁNCHEZ, Los delitos contra la integridad moral, cit., págs. 47 y 48.

${ }^{100}$ Cfrs. GARCÍA ARÁN, "La protección penal de la integridad moral”, cit., pág. 1253.

${ }^{101}$ Cfrs. GARCÍA ARÁN, "La Protección penal de la integridad moral”; cit., págs. 1253 y 1254. 
de la integridad moral ocasionando un sentimiento de humillación, degradación y cosificación del sujeto al cual van dirigidos.

\section{La ¿diferencia? entre las conductas de los números $1^{\circ}$ y $2^{\circ}$ del art. 173 $\operatorname{del~Cp}$}

Una vez delimitadas cuáles sean las conductas típicas contenidas en los dos primeros números del art. 173, el paso siguiente radica en determinar la diferencia que existe entre las mismas a fin de poder justificar la regulación autónoma y diferenciada de los dos tipos delictivos. Efectivamente, al modificar la Ley Orgánica 11/2003 la ubicación sistemática del delito de violencia doméstica habitual y colocarlo entre los atentados contra la integridad moral, es evidente, tal como hemos puesto de manifiesto en epígrafes anteriores, que el bien jurídico que se protege es la integridad moral. Consecuentemente, la diferencia entre el $\mathrm{n}^{\circ} 1$ y el $\mathrm{n}^{\mathrm{o}} 2$ del art. 173, necesariamente tiene que radicar en la conducta realizada, es decir, en el modo de atentar contra la integridad moral, si es que quiere encontrarse algún fundamento legítimo para esta regulación diferenciada ( $\mathrm{y}$ claramente agravada).

En esta línea diferenciadora, HUERTA TOCILDO"102 afirma que "los malos tratos habituales a que ahora se refiere el art.173.2 CP no guardan ninguna relación jerárquica con los tratos degradantes del art. 173.1 o, por mejor decirlo, no se comportan como tipos agravados de una conducta básica de trato degradante que suponga un grave menoscabo de la integridad moral. Los elementos componentes de las conductas respectivamente sancionadas en cada uno de estos dos tipos penales impiden, a mi modo de ver, que entre ambos pueda establecerse esa relación de tipo básico-tipo agravado ya que, mientras que el artículo 173.1 se conforma con un único trato degradante, si bien exige que sea apto para menoscabar en forma grave la integridad moral, en el art. 173.2 no se alude para nada a la gravedad del maltrato fisico o psiquico y sí, en cambio, a la necesidad de que sea habitual, es decir, que no se trate de un único acto puntual de violencia física o psíquica".

Antes de comenzar con el análisis de la postura mantenida por la autora citada, quisiera señalar que considero que no se trata de determinar la existencia de un tipo básico (el art. 173.1 del Cp) y un tipo agravado (el art. 173.2 del Cp) sobre la base de la concurrencia de la habitualidad del comportamiento en el segundo supuesto, sino que lo que pretendo es demostrar si la conducta regulada es la misma que describe el número primero de ese precepto o no. Una vez delimitado esto, y caso de llegar a una respuesta afirmativa como considero que sería el caso, habría que encontrar el fundamento de la agravación recogida en el número segundo en algo distinto de la conducta típica. Pero vayamos por partes.

102 HUERTA TOCILDO, "Los límites del Derecho penal en la prevención de la Violencia doméstica", en Estudios penales en recuerdo del Profesor Ruiz. Antón, Octavio de Toledo y Ubieto/Gurdiel Sierra/Cortés Bechiarelli (coords.), Valencia 2004, pág. 516. 
Núñez Castaño - La violencia doméstica en la legislación española...

Es evidente que la Profesora Huerta tiene razón al afirmar que el número primero del art. 173 establece la necesidad de que el trato degradante que se produzca con el comportamiento del sujeto activo determine un grave menoscabo en la integridad moral de la víctima; así lo establece expresamente el precepto. Comparto, aunque sólo parcialmente la afirmación de que el art. 173.1 se conforma con "un único trato degradante"; y digo sólo parcialmente, porque entiendo, tal como he manifestado antes, que el "trato degradante" no es la acción en sí misma, sino el resultado que la misma produce. Consecuentemente, si se produce un trato degradante grave habrá un delito del art. 173.1, si son varios claramente diferenciados, habrá un concurso. Al margen de esto, sí comparto la afirmación de que basta con una única acción para que se produzca ese trato degradante del art. 173.1 siempre que sea apto para menoscabar en forma grave la integridad moral; pero ello no obsta, para que ese trato degradante también se pueda producir por varias acciones o incluso por un comportamiento reiterado. $\mathrm{Y}$ es aquí donde discrepo de la postura de la Profesora Huerta.

Efectivamente, el número segundo del art. 173 no hace referencia alguna a la gravedad del comportamiento, sino a la babitualidad de los comportamientos de violencia física o psíquica; es decir, tal como hemos afirmado anteriormente, lo realmente relevante a efectos de este precepto, la esencia del mismo radica justamente en la persistencia o reiteración en el tiempo de la conducta violenta que provoca un estado o clima de violencia y angustia permanente que desemboca en un sentimiento de miedo, humillación, degradación e inferioridad en las víctimas de la misma. Y esto es, en mi opinión, lo que configura la conducta descrita en el número segundo del art. 173 como un trato degradante grave. En otras palabras, lo "grave" del art. 173.2 es la habitualidad, que es la que produce el clima de humillación y angustia que provoca el menoscabo grave de la integridad moral.

De hecho, incluso resulta perfectamente posible que muchos de los distintos actos concretos que configuran la habitualidad del delito del art. 173.2, considerados individualmente no sean necesariamente graves, esta "gravedad", este desvalor específico nace de la "erosión continuada" de la integridad moral, de la atmósfera de terror y angustia ocasionada, de la humillación y envilecimiento producidos por la suma de todos los distintos actos concretos.

En mi opinión, la reiteración de actos violentos que provocan un permanente estado de humillación o clima de violencia, implica sin lugar a dudas un menoscabo grave de la integridad moral. El problema consiste en determinar si constituye o no el "trato degradante" al que se refiere el número primero del precepto analizado.

Otra argumentación distinta respecto a la distinción entre los dos números del art. 173, radicaría, como ya he dicho, en afirmar que la diferencia se encuentra en el modo de atentar contra la integridad moral: así, en el caso del delito de violencia doméstica consistiría en el empleo de violencia física o psíquica, mientras 
que en el delito recogido en el $\mathrm{n}^{\circ} 1$ consistiría en infligir el trato degradante por una vía distinta a la violencia ${ }^{103}$.

A este respecto, señala RAMÓN RIBAS ${ }^{104}$ que "...las conductas del art. 173.1 no deben ser necesariamente violentas". Y evidentemente tiene razón; no deben ser necesariamente violentas, pero no existe impedimento alguno para que sí puedan serlo. De hecho, ya hemos afirmado que el trato degradante se puede producir tanto por violencia, física o psíquica, como por medios fraudulentos, como por cualquier otra vía, porque el legislador no quiso limitar las modalidades comisivas, con lo cual cualquier modo de provocar el trato degradante es típico a efectos del art. 173.1 del Código penal.

En definitiva, de lo que se trata es de determinar si la conducta descrita en el art. 173.2, esto es, "ejercer habitualmente violencia física o psíquica", se puede considerar o no como "trato degradante" descrito en el número primero del mencionado artículo. Si el art. 173.1 no establece ningún tipo de limitación en las modalidades comisivas, consecuentemente, el trato degradante al que se refiere se puede infligir mediante actos de violencia física y/o psíquica. El problema radicaría entonces, en constatar la existencia de la "gravedad" que exige el número primero del art. 173 del Cp.

A este respecto, incluso quienes han negado la posibilidad de identificar las conductas de los dos tipos delictivos, entienden, en relación con la descrita en el art. 173.2, que "...cabe pensar que la conducta tipificada debe considerarse grave ex lege: concurriendo un ejercicio habitual de violencia, el comportamiento no puede sino estimarse un grave atentado a la integridad moral ${ }^{1,105}$. Evidentemente, esta nota de gravedad que viene ineludiblemente unida al trato degradante por un lado y al menoscabo a la integridad moral por otro, determina que haya que analizar si los comportamientos de violencia doméstica habitual reflejan o no en esencia tanto la conducta como la gravedad necesaria para constituir el tipo del art. 173.1 Cp.

De este modo, la gravedad del trato degradante, tal como ya lo hemos manifestado, debe hacerse radicar en la producción de una degradación o humillación, que implica la pérdida de las cualidades inherentes al hecho mismo de ser persona, instrumentalizándola y reduciéndola a la condición de objeto ${ }^{106}$. Si, tal como ya hemos visto en los epígrafes dedicados al bien jurídico y a la conducta típica regulada en el art. 173.2 del Código penal, el núcleo esencial del delito de violencia habitual, el fundamento básico radica en el entorno de violencia, el clima

\footnotetext{
103 Como ya señalé, éste parecía ser el planteamiento de OLMEDO CARDENETE, cfrs., supra nota 86.

104 RAMÓN RIBAS, Violencia de género y violencia doméstica, cit, pág. 62

105 RAMÓN RIBAS, Violencia de género y violencia doméstica, cit., pag. 62, nota 88.

106 PÉREZ MACHIO, "Concepto jurídico de mobbing, bien jurídico lesionado y su tutela jurídico penal", Revista Electrónica de Derecho Penal y Criminología, $\mathrm{n}^{\circ}$ 6, 2004, pág. 16, http://criminet.ugr.es/recpc, 06-06 (2004), consultada el 25 de Octubre de 2008.
} 
Núñez Castaño - La violencia doméstica en la legislación española...

de temor o la situación de angustia, a causa de la reiteración de determinados comportamientos, que provocan una degradación y humillación para la persona que la sufre, reduciéndola a una condición inferior a la de persona, de mero objeto, resulta evidente que es precisamente esta reiteración, la creación de ese entorno violento, lo que constituye la "gravedad" del comportamiento descrito, y que provoca las mismas consecuencias que la conducta descrita en el número primero del art. 173 Cp.

De hecho, la reiteración y prolongación en el tiempo de determinados comportamientos que, aisladamente considerados, pudieran no reunir la nota de "gravedad", les atribuye una intensidad suficiente como para que sean adecuados para producir la grave afección del bien jurídico (integridad moral) exigida por el tipo $^{107}$, y ésta es precísamente la característica que tradicionalmente se ha destacado de las conductas de violencia doméstica habitual tanto doctrinal como jurisprudencialmente ${ }^{108}$.

Consecuentemente, si la realización de violencias físicas o psíquicas constituyen modalidades comisivas del número primero del art. 173 del Cp, y si la habitualidad de los comportamientos, en cuanto creación de un determinado clima y determinados sentimientos en las víctimas, determina la gravedad exigida en la afección al bien jurídico que se protege en ambos tipos penales, se puede afirmar, en mi opinión, que la conducta descrita en el número segundo, no deja de ser una modalidad típica del número primero.

De hecho, y antes de que razones ajenas al ámbito estrictamente jurídico, o más concretamente, jurídico penal, interviniesen en la regulación legislativa de la Violencia doméstica ésta era la convicción del legislador. Durante el debate parlamentario relativo a la aprobación del Código penal de 1995, donde se incluye por primera vez el delito de "atentados contra la integridad moral", se llegó a la conclusión de que las conductas que debían quedar absorbidas por este precepto respondían esencialmente a comportamientos que constituyeran trato degradante generados tanto en el ámbito familiar como en el laboral ${ }^{109}$; es decir, la sanción de los denominados tratos degradantes iba a encontrar su principal campo de acción en los ámbitos familiar y de trabajo.

\footnotetext{
107 PÉREZ MACHIO, ult. op. cit., pág. 13, si bien refiriéndose al concepto de “mobbing”.

108 Vid. supra epígrafe III.2

109 Cfrs. la enmienda núm. 723, presentada por el Grupo parlamentario IU-IC, de supresión del artículo por entender que los tratos degradantes específicos de determinadas relaciones (familia y trabajo) debían ser ubicados sistemáticamente en el lugar correspondiente, Boletín Oficial de las Cortes Generales, Serie A, no 77-1, de 26 de Septiembre de 1994, pág. 29, citado por PÉREZ MACHIO, ult. op. cit., pág. 50.
} 


\section{V. ¿Resulta justificada una regulación autónoma del delito de violencia doméstica habitual en el art. 173.2 del Código penal?}

Sobre la base de todo lo dicho hasta este momento, y entendida la integridad moral como el derecho de toda persona a recibir un trato acorde con su condición de ser humano libre y digno, y ver respetadas su personalidad y voluntad, no siendo degradado a una condición inferior a la de persona, resulta innegable que las situaciones de violencia doméstica, en su inmensa mayoría suponen, sea cual sea el resultado lesivo que impliquen, un auténtico caso de atentado contra la integridad moral. Ahora bien, eso lo suponen ahora con la nueva ubicación del delito de violencia doméstica habitual en el art. 173.2 y lo suponían antes con la primigenia redacción del precepto dedicado a los atentados contra la integridad moral (art. 173.1 actual). Mantener los dos preceptos no sólo resulta reiterativo por regular lo ya regulado, sino contraproducente sobre todo por los problemas en materia concursal que se van a derivar de esta regulación.

A este respecto, afirma MUNOZ CONDE ${ }^{110}$ que una vez que la Ley Orgánica 11/2003, ha convertido "...las lesiones, los golpes y los malos tratos de obra cometidos en este ámbito automáticamente en delito, conforme a lo dispuesto abora en el art. 153, no parecía necesario ampliar aún más el ámbito de intervención penal". Y no sólo comparto plenamente esta afirmación, al margen de las serias dudas que me ocasiona la regulación actual (a partir de la Ley Orgánica 1/2004, sobre medidas de protección integral contra la violencia de género) del art. 153 del $\mathrm{Cp}^{111}$, sino que voy aún más allá. Si, como hemos visto, la conducta de violencia doméstica habitual en tanto que generadora de un entorno violento y degradante para quienes lo sufren, no deja de ser sino una modalidad comisiva del atentado a la integridad moral recogido en el art. 173.1, ¿cuál es la razón de que se tipifique autónomamente este delito?

Antes de la reforma de la Ley $11 / 2003$, se argumentaba que el plus de desvalor de estas conductas radicaba en la habitualidad por un lado, y el círculo de sujetos entre quienes se producía por otro. Tras la reforma penal, como hemos señalado, resulta obvio que la habitualidad, ya no constituye ningún plus de desvalor del comportamiento, sino la esencia misma del comportamiento, al configurar la gravedad necesaria para suponer el ataque a la integridad moral. Con ello, el único plus, la única razón de una tipificación autónoma del delito de violencia doméstica habitual, radica en el círculo de sujetos que se ven afectados por este tipo de comportamientos. Ahora bien, ¿ese plus de desvalor es suficiente para justificar una regulación autónoma del delito de violencia doméstica habitual o hubiera sido más adecuado optar por otro tipo de regulación?

110 MUÑOZ CONDE, Derecho penal, Parte especial, 15ª ed., 2004, cit., pág. 187.

111 No obstante, como ya he dicho, a pesar de que, en mi opinión, el actual artículo 153 pudiera adolecer claramente de inconstitucionalidad en su redacción, lo cierto es que esa "claridad" la ha tenido el Tribunal Constitucional en su Sentencia 59/2008, de 14 de Mayo, para afirmar claramente la constitucionalidad del mismo. 
Núñez Castaño - La violencia doméstica en la legislación española...

En este punto no niego que la realización de determinados comportamientos violentos, sobre todo reiterados y prolongados en el tiempo, pueden tener unos efectos y consecuencias mucho más graves que las mismas conductas realizadas contra personas que no se encuentran dentro de ese círculo; ni tampoco niego que el desvalor de ese tipo de comportamientos sea mayor y que sea preciso que el Derecho penal le dé cobertura. Sin embargo creo que la regulación de un tipo autónomo referido a la violencia doméstica habitual y configurado como atentado contra la integridad moral, sólo va a provocar situaciones conflictivas, sobre todo a nivel concursal tanto respecto a su relación con el art. $153^{112}$, con el art. $147.1^{113}$, o con el resto de los tipos delictivos que afectan a bienes jurídicos eminentemente personales ${ }^{114}$. Pero sobre todo, plantea un importante problema concursal en relación con la posibilidad de apreciar un concurso entre los dos números del art. 173 del Código penal.

Efectivamente, al encontrarse actualmente el delito de violencia habitual en el ámbito doméstico entre los delitos contra la integridad moral, necesariamente supone, como hemos señalado, un ataque a la integridad moral; consecuentemente, de lege data, el ejercicio habitual de violencia en el ámbito doméstico puede ser sancionado en virtud del número primero o del número segundo del art., 173. Con ello, al ser los dos preceptos ataques contra la integridad moral, parece obligado negar la posibilidad de apreciar un concurso entre ambas infracciones. En este sentido se pronuncia, ACALE SÁNCHEZ ${ }^{115}$ afirmando que

112 Así, por ejemplo, la especial problemática en torno a la posibilidad o no de aplicación conjunta del art. 153 y el art. 173.2, que ha hecho correr ríos de tinta entre la doctrina en relación con si los concretos actos de violencia que se repiten de manera reiterada pueden o no castigarse separadamente del concreto delito de violencia habitual, sobre la base de una posible lesión del ne bis in idem, vid., en este sentido, MUÑ CONDE, Derecho Penal, Parte especial, $15^{\mathrm{a}}$ ed., 2004, cit., pág. 190; a favor de la existencia de concurso de delitos entre ambos artículos, vid. RAMÓN RIBAS, Violencia de género y violencia doméstica, cit., pág. 66 y ss.

113 No olvidemos que el art. 147.1 in fine, regula una suerte de habitualidad, difícilmente justificable, al establecer que se aplicará este precepto cuando "...en el plazo de un año, haya realizado cuatro veces la acción descrita en el art. 617 de este Código”. Así, por ejemplo, MUÑOZ CONDE, Derecho penal, Parte especial, ibidem, mantiene que si coincide la violencia habitual del art. 173.2 con el supuesto previsto en el art. 147.1 in fine, "...la única posibilidad de distinguir estos supuestos de lesiones y el delito contra la integridad moral es exigir para la aplicación de este último que se dé el menoscabo grave de la integridad moral a que se refiere el art. 173.1", advirtiendo que la subsunción de los hechos en los dos preceptos no llevaría asociada su simultánea aplicación conforme a la regla concursal del art. 173.2, ya que se infringiría el principio ne bis in idem; del mismo parecer, aquí sí, es RAMÓN RIBAS, Violencia de género y violencia doméstica, cit., pág. 73, quien afirma que "...si, por el contrario, por haberse producido el contenido del injusto del delito del articulo 173.2 fuera éste aplicable, podría concurrir con las diversas infracciones, individualmente consideradas, del articulo 153, pero no con su conjunta contemplación (suma de infracciones más simple habitualidad) en el artículo 147.1).

114 Vid. por todos, NÚÑEZ CASTAÑO, El delito de malos tratos en el ámbito familiar, cit., págs. 125 y ss.

115 ACALE SÁNCHEZ, "Los nuevos delitos de maltrato singular y de maltratos habituales en determinados ámbitos", en Revista de Derecho Penal y Criminología, no 15, enero 2005, págs. 34 y 35; también CAMPOS CRISTÓBAL, "Tratamiento penal de la violencia de género", en La nueva Ley 
si el bien jurídico protegido por el art. 173.2 se identifica con la integridad moral "... Los números $1^{\circ}$ y $2^{\circ}$ del artículo 173 no podrían entran en concurso de delitos pues existiría «ne bis in idem»", afirmando que "...se trataría de tipos básico y agravado en el que la repetición de los actos singulares constitutivos de trato degradante asi como la relación especial existente entre los sujetos activos y pasivos servirian de fundamento para la agravación. De tal forma que, por este mismo motivo, los actos singulares constitutivos de trato degradante no podrian entrar a configurar la habitualidad del maltrato habitual, pues todas las conductas que supusieran violación de lo dispuesto en el art. 173.2 serían a la vez violación de lo dispuesto en el art. 173.1 (en virtud del principio de subsidiariedad -tácita-del art. 8.2)". ${ }^{116}$.

Se trataría, por tanto, de un concurso de normas que se resolvería a favor del número 2 del art. 173 del Código penal, con lo que se dejaría prácticamente vacío de contenido el número primero del mencionado precepto si tenemos que excluir del mismo todos aquellos comportamientos de trato degradante que se realicen en un determinado entorno doméstico. No olvidemos, que tal como hemos señalado, el legislador de 1995 ya tenía la convicción de que el ámbito familiar y el laboral eran los dos principales campos de actuación del primigenio delito contra la integridad moral ${ }^{117}$.

En mi opinión, dado el paralelismo innegable de los atentados contra la integridad moral y la conducta de violencia habitual, hasta el punto, como hemos señalado, de que es precisamente la reiteración y habitualidad del comportamiento lo que convierte la conducta en un trato degradante, resultaría imposible apreciar un concurso de delitos entre ambos preceptos so pena de valorar dos veces el mismo contenido de injusto y vulnerar con ello el ne bis in idem. La opción de lege data radica en un concurso de normas, que tal como hemos explicado encuentra su único fundamento en la especialidad de los sujetos involucrados en este tipo de comportamientos.

contra la Violencia de Género. L.O. 1/2004, de 28 de Diciembre, Boix Reig/Martínez García (coords.), Madrid, 2005, págs. 261 y ss.

116 En este mismo sentido, vid. GÓMEZ RIVERO, "Algunos aspectos del delito de malos tratos", cit., pág. 82, afirma que "...el delito de malos tratos desborda y supera el contenido de desvalor propio de la integridad moral para adoptar una perspectiva más amplia que la de éste....(...) el precepto se orienta a proteger la dignidad y bienestar de la persona, que se ve atacada por la bumillación y vejación que supone su sometimiento a conductas violentas, aspectos éstos que protege en exclusiva el delito contra la integridad moral. Por ello, apreciar en tales casos un concurso de delitos supondría castigar dos veces el mismo contenido de desvalor"; OLMEDO CARDENTE, El delito de violencia habitual en el ámbito doméstico, cit., pág. 145; MARÍN DE ESPINOSA CEBALLOS, La violencia doméstica, cit., pág. 262.

117 Sin embargo, en contra de esta postura y partidario de aceptar la existencia de un concurso de delitos entre ambos números del art. 173, RAMÓN RIBAS, Violencia de género y violencia doméstica, cit., págs. 78 y ss., quien afirma que "sostener la incompatibilidad concursal entre los delitos tipificados en los dos primeros numeros del artículo 173 no es, sin embargo, una conclusión necesaria”, considerando que si en la erosión continuada de la integridad moral es posible individualizar conductas que sean subsumibles en el primer número del artículo 173 y que exijan un castigo separado, podrá apreciarse el concurso de delitos. 
Núñez Castaño - La violencia doméstica en la legislación española...

Ahora bien, considero que esta especialidad o este plus de desvalor, no fundamenta la existencia de un tipo autónomo de violencia habitual integrado entre los ataques contra la integridad moral. La solución podría venir por la vía de cualificaciones y/o agravantes, bien genéricas, bien específicas, que permitan una mayor pena para ese tipo de comportamientos ${ }^{118}$. Así, por ejemplo, se podría acudir para agravar el castigo a la circunstancia mixta de parentesco (obviamente modificada en algunos aspectos), o, más adecuadamente en mi opinión, establecer una serie de cualificaciones dentro del mismo precepto, para aquellos supuestos en los que la conducta descrita, esto es infligir trato degradante se realice dentro de un determinado círculo de personas, de modo similar a como se regulan las cualificaciones del art. 180 del Código penal en relación con determinados delitos de agresión sexual ${ }^{119}$ cuando se cometan entre sujetos a los cuales les unan determinadas relaciones $y / o$ se encuentren en una especial situación de vulnerabilidad. Lo relevante en estos casos sería, no tanto el parentesco en sí, sino el abuso de superioridad, de confianza, el prevalimiento que se genera de las relaciones entre determinados sujetos, en este caso, unidos por lazos familiares, de convivencia (actual o no), etc. ${ }^{120}$.

En resumen, en mi opinión, la regulación autónoma del delito de violencia habitual en el ámbito doméstico supone una reiteración de regulaciones que lo único que va a provocar son conflictos a la hora de determinar el tipo delictivo aplicable. Por todo ello, considero que el ejercicio de violencia física o psíquica habitualmente constituye un trato degradante que ocasiona un menoscabo grave de la integridad moral, sobre la base precisamente de esa reiteración de comportamientos dentro de un determinado ámbito como es el doméstico, provocando un estado de temor y humillación constante desde una posición de superioridad del sujeto activo. Así pues, sería perfectamente aplicable el tipo contenido en el artículo 173.1 del Código penal, basándose en que la habitualidad de las conductas violentas provocan precisamente el trato degradante típico del que habla el precepto. Si esa violencia realizada habitualmente recae sobre distintos sujetos pasivos podrá apreciarse un concurso ideal de delitos respecto de todos aquellos sujetos a los que se les haya menoscabado la integridad moral de forma grave $^{121}$.

\footnotetext{
118 Ya previamente, NÚÑEZ CASTAÑO, El delito de malos tratos en el ámbito familiar, cit., pág. 145.

${ }^{119} \mathrm{El}$ art. 180 establece una cualificación respecto de las conductas realizadas en los arts. 178 y 179, cuando la víctima sea especialmente vulnerable, por razón de su edad, enfermedad o situación (número $3^{\circ}$ ) y cuando para la ejecución del delito, el responsable se haya prevalido de una relación de superioridad o parentesco, por ser ascendiente, descendiente o hermano, por naturaleza o adopción, o afines con la víctima (número $4^{\circ}$ ).

120 En este sentido, respecto a las cualificaciones recogidas en el art. 180. $4^{\circ}$ del Código penal, señala MUÑOZ CONDE, Derecho penal, Parte especial, 16a ed., 2007, cit., pág. 224, que "no se trata, por tanto, del quebrantamiento de un especial deberpara el autor de abstenerse de este tipo de acciones (...) sino, como ya proponiamos en la $11^{a}$ ed. (p.191) de que la relación parental de lugar a una relación de prevalimiento que, de todos modos, normalmente irá implícita en la propia intimidación”.

121 En este sentido, MUÑOZ SÁNCHEZ, Los delitos contra la integridad moral, cit., pág. 55, afirma que los tratos degradantes reiterados que se produzcan sin romperse la unidad natural de acción
} 
Desde este planteamiento, y de lege ferenda, a efectos de evitar superposiciones en la regulación penal que determinen la existencia de problemas concursales de difícil solución en muchos casos, o que impliquen la vulneración de principios básicos en otros, considero que lo correcto sería eliminar la configuración del delito de violencia habitual en el ámbito doméstico como delito autónomo dentro de los atentados contra la integridad moral, castigando estos comportamientos como un supuesto del actual número primero del art. 173. Al mismo tiempo, y a fin de contemplar el total desvalor que este tipo de conductas implica al realizarse entre un concreto círculo de sujetos, donde la intensidad de los resultados puede ser más grave que en otros ámbitos, debiera regularse un tipo cualificado en el cual se haga referencia exclusivamente a la agravación de las sanciones cuando el trato degradante se infligiera entre los sujetos señalados.

Resulta evidente la importancia y trascendencia de estas situaciones, así como la gravedad de las consecuencias de estos comportamientos. Ahora bien, aunque la reprochabilidad de estos casos y conductas puedan provocar respuestas emotivas y violentas por parte de la sociedad, el legislador no puede perder la frialdad y objetividad, dejándose llevar por el clamor social; por el contrario, debe enfrentarse con este tipo de situaciones con desapasionamiento, y desde el más estricto respeto a los principios que informan el ordenamiento jurídico-penal. Es innegable que el Derecho penal puede contribuir a poner freno a esta situación,

(la negrita es nuestra) se considerarán como integrantes de un mismo hecho, al tiempo que afirma que si mediante un solo hecho se produce un trato degradante a varias personas, se apreciará un concurso ideal de delitos. A la misma conclusión llegaríamos a partir de un concepto significativo de acción, que cada vez cuenta con un mayor número de defensores, sobre la base de que tal como afirma MUÑOZ CONDE, Derecho penal, Parte General, $7^{a}$ ed., Valencia 2007, págs. 214 y 215 , "en la determinación del concepto de acción no es suficiente con la constatación de los aspectos puramente causales y finales de la misma, sino que es necesario también situarlos en un determinado contexto intersubjetivo que es lo que le da su sentido comunicativo, social y/ o jurídico, es decir, su significado. En definitiva, lo relevante es esta capacidad expresiva o significativa del comportamiento humano en un determinado contexto de comunicación intersubjetiva". Sobre el concepto significativo de acción, vid. VIVES ANTÓN, Fundamentos del sistema penal, Valencia 1996, pág. 197 y ss.; FLETCHER, Conceptos básicos del Derecho penal, (trad. y notas de Muñoz Conde), Valencia 1997, págs. 93 y ss; MARTÍNEZ-BUJÁN PÉREZ, "La concepción significativa de la acción de T.S. Vives y sus correspondencias sistemáticas con las concepciones teleológico-funcionales del delito", en Libro Homenaje al Dr. Marino Barbero Santos, Nieto Martín (coord..), Cuenca, 2001, 1144 y ss.; ALCACER GUIRAO, "Como cometer delitos con el silencio. Notas para un análisis del lenguaje de la responsabilidad", en Estudios penales en recuerdo del Profesor Ruiz, Antón, cit., págs. 38 y ss.; BUSATO, “Actio libera in causa y acción significativa”, en Problemas actuales del Derecho penal y de la Criminología, Estudios penales en memoria de la Profesora Dra. María del Mar Díaz Pita, Muñoz Conde (direct.), Valencia 2008, págs. 502 y ss. En mi opinión, el significado concreto que en ese determinado contexto intersubjetivo le da un sentido jurídico a efectos de apreciación de un delito del art. 173, lo constituye la repetición de los comportamientos, la habitualidad, de tal forma que los hechos aisladamente considerados pierden sentido en relación con los delitos contra la integridad moral (al margen de que pudieran tenerlo respecto de otros tipos delictivos). De este modo, lo realmente relevante, lo que le consigna un significado válido a efectos penales, es la reiteración de las conductas que provocan el clima de violencia, es decir, el hecho típico a considerar a efectos del art. 173 no son los concretos actos violentos que se realicen, sino el clima de violencia que desemboca en el atentado contra la integridad moral. 
Núñez Castaño - La violencia doméstica en la legislación española...

pero ni es el único medio ni, desde luego, el más adecuado para ello. Al margen de todo esto, lo realmente importante, es evitar que se legisle "a impulsos", como reacción a peticiones derivadas de casos concretos; porque esa regulación a base de parches y soluciones momentáneas lo único que va a provocar son problemas a la hora de la aplicación de los tipos penales. La regulación penal debe constituir un todo coordinado y sistematizado, de manera que se eviten posibles superposiciones de regulaciones concretas que provoquen justo el efecto contrario al perseguido.

Sirvan de modelo las palabras de BUSTOS RAMÍREZ ${ }^{122}$ cuando afirmaba que "....si hacer politica significa entre varias alternativas elegir una para la solución de un problema, en un Estado social y democrático de Derecho no cualquier alternativa es válida. Y si esa política es una política criminal en la medida que la opción elegida afecta gravemente a la persona, los limites se acentúan de modo considerable. Estamos hablando de limites que surgen de la ética (el fin no justifica los medios), de los derechos fundamentales (esto es, la visión bistórica nacional de los derechos bumanos) y los principios que dieron nacimiento al Estado moderno (libertad, igualdad y solidaridad)", entendiendo que puede "...postularse un reforzamiento de los instituciones de control y también del sistema de Derecho penal, pero manteniendo los principios garantistas ${ }^{, 23}$.

122 Cfrs. BUSTOS RAMÍREZ/HORMAZÁBAL MALAREE, Lecciones de Derecho penal, cit., pág. 28.

${ }^{123}$ Cfrs. BUSTOS RAMÍREZ/HORMAZÁBAL MALAREE, ult. op. cit., pág. 29. 
REJ - Revista de Estudios de la Justicia - No 12 - Año 2010

\section{BIBLIOGRAFÍA}

* ACALE SÁNCHEZ, María, "Los nuevos delitos de maltrato singular y de maltratos habituales en determinados ámbitos", en Revista de Derecho Penal y Criminología, no 15, enero 2005.-

El delito de malos tratos físicos y psíquicos en el ámbito familiar, Valencia 2000.

* AlCACER GUIRAO, Rafael, "Como cometer delitos con el silencio. Notas para un análisis del lenguaje de la responsabilidad”, en Estudios penales en recuerdo del Profesor Ruiz. Antón,

* Alonso ÁlAmo, Mercedes, "Protección penal de la igualdad y Derecho penal de Género", Cuadernos de Política Criminal, nº 95, 2008.

* BARQUín SANZ, Jesús, Los delitos de tortura y tratos inbumanos o degradantes, Madrid 1992.

* Boldova PASAMAR, Miguel y RUEDA MARTín, María "Consideraciones políticocriminales en torno a los delitos de violencia de género", en La reforma penal en torno a la violencia doméstica y de género, Boldova Pasamar/Rueda martín (coords.), Barcelona, 2006.

"El nuevo tratamiento de la violencia habitual en el ámbito familiar, afectivo o similar tras las reformas del 2003 del Código penal español", en Revista de Derecho penal y Criminología, $2^{\mathrm{a}}$ época, 2004, no 14. 14-2-2004

"La discriminación positiva de la mujer en el ámbito penal", en La Ley, no 6146,

* BOLEA BARDÓN, Carolina, "En los límites del Derecho penal frente a la violencia doméstica y de género", en Revista Electrónica de Derecho Penal y Criminología, 2007, http://criminet.ugr.es/recpc, 09-02 (2007), consultada el 25 de Octubre de 2008.

* BUSATO, Paulo, "Actio libera in causa y acción significativa", en Problemas actuales del Derecho penal y de la Criminología, Estudios penales en memoria de la Profesora Dra. María del Mar Díaz Pita, Muñoz Conde (direct.), Valencia 2008.

* BUSTOS RAMÍREZ, Juan y HORMAZÁBAL MALAREE, Hernán, Lecciones de Derecho penal. Parte general, Madrid 2006.

Nuevo sistema de Derecho penal, Madrid 2004.

* CAMPOS CRISTÓBAL, Raquel, "Tratamiento penal de la violencia de género", en La nueva Ley contra la Violencia de Género. L.O. 1/2004, de 28 de Diciembre, Boix Reig/Martínez García (coords.), Madrid, 2005.

* CARBonell mateu, Juan y GONZÁlez CUSSAC, José, en Vives Antón y otros, Comentarios al Código penal de 1995, vol. I, Valencia 1996.

* COLMENERO MÉNDEZ DE LUARCA, Miguel, "La discriminación positiva en el ámbito penal", en La discriminación positiva, Manuales de Formación continuada, Consejo General del Poder Judicial, Madrid 2006.

* CORTÉS BECHIARELLI, Emilio, "Novedades legislativas en materia de maltrato doméstico (Ley Orgánica 11/2003, de 29 de Septiembre): propuestas de interpretación", en Estudios penales en recuerdo del Profesor Ruiz. Antón, Valencia 2004.

El delito de malos tratos familiares. Nueva regulación, Madrid-Barcelona, 2000.

* CUENCA I GARCÍA, María Josep, "La violencia habitual en el ámbito familiar", Revista Jurídica de Cataluña, 1998.

* DE LA CUESTA ARZAMENDI, José, "Tortura y otros atentados contra la integridad moral”, en Estudios Penales y Criminológicos, XXI, 1998.

* DE VEGA RUIZ, José, Las agresiones familiares en la violencia doméstica, Pamplona 1999.

* DEL MORAL GARCÍA, Antonio, "El delito de violencia habitual en el ámbito familiar", en Delitos contra las personas, Manuales de formación continuada, Consejo General del Poder Judicial, Madrid 1999.

* DEL ROSAL BLASCO, Bernardo, "Torturas y otros delitos contra la integridad moral en el Código penal de 1995”, en La ciencia del Derecho penal ante el nuevo siglo, Libro Homenaje al 
Núñez Castaño - La violencia doméstica en la legislación española...

Profesor Cerezo Mir, Diez Ripollés/Romeo Casabona/Gracia Martín/Higuera Guimerá (editores), Madrid 2002.

* DÍAZ PITA, María del Mar, "El bien jurídico protegido en los nuevos delitos de tortura y atentado contra la integridad moral", en Estudios penales y criminológicos, $\mathrm{n}^{\circ} \mathrm{XX}, 1997$.

* DOLZ LAGOS, Manuel, "Violencia doméstica habitual: mitos y realidades", La Ley, 2000.

* Faraldo CABANA, Patricia, "Razones para la introducción de la perspectiva del género en el Derecho penal a través de la Ley Orgánica 1/2004, de 28 de Diciembre, de medidas de protección integral contra la violencia de género", en Revista Penal, nº 17, 2006.

* FELIP SABORIT, David y RAGUES i VALLES, Ramón, Lecciones de Derecho penal. Parte Especial, Silva Sánchez (director), Barcelona 2006.

* FERRAJOLI, Luigi, Derecho y Razón, Ed. Trotta, Madrid 1995.

* FLETCHer, George, Conceptos básicos del Derecho penal, (trad. y notas de Muñoz Conde), Valencia 1997.

* GALÁN MUÑOZ, Alfonso, "De la «Violencia doméstica» a la «Violencia de género»: ¿Un paso fallido hacia el Derecho penal del enemigo?”, en Estudios sobre la Tutela penal de la Violencia de Género, Núñez Castaño (directora), Valencia 2009.

* García ÁlvareZ, Pastora y DEL CARPIO DELGADO, Juana, El delito de malos tratos en el ámbito familiar. Problemas fundamentales, Valencia 1999.

* GARCÍA ARÁN, Mercedes, "La protección penal de la integridad moral", en La ciencia del Derecho penal ante el nuevo siglo, Libro Homenaje al Profesor Cerezo Mir, Diez Ripollés/Romeo Casabona/Gracia Martín/Higuera Guimerá (editores), Madrid 2002.

* GÓMEZ NAVAJAS, Justa, "La violencia en el ámbito familiar: ¿una reforma inacabada o inacabable? Consideraciones sobre los artículos 153 y 173.2 del Código penal”, en Revista de Derecho y Proceso penal, n 11, Enero 2004.

* GÓMEZ RIVERO, María del Carmen, “Algunos aspectos del delito de malos tratos”, en Revista penal, nº, Julio 2000.

* GONZÁLEZ CUSSAC, José, "La intervención penal contra la violencia de género desde la perspectiva del principio de proporcionalidad", en Tutela procesal frente a becho de violencia de género, Universitat Jaume I, Castellón, 2007.

"Delitos de torturas y otros tratos degradantes (Delitos contra la integridad moral)", en Estudios sobre el Código penal de 1995, parte Especial.

* GONZÁLEZ RUS, Juan, “Tratamiento penal de la violencia sobre personas ligadas al autor por relaciones familiares, afectivas o legales, después de la L.O. 14/1999, de 9 de Junio", en Revista Jurídica de Andalucía, no 30, 2000.

"Violencia habitual sobre personas ligadas al agresor por relaciones familiares, afectivas o legales", en Addenda al Curso de Derecho penal español, Parte especial, 1999.

* GRACIA MARTIN, José, en Gracia Martín/ Diez Ripollés (coords.), Comentarios al Código penal. Parte especial, Tomo I, Valencia 1997.

- GRIMA LIZANDRA, Vicente, Los delitos de tortura y tratos degradantes por funcionarios públicos, Valencia 1998.

* HASSEMER, Winfried, "Crisis y características del moderno Derecho penal", en Actualidad penal, 1993.

* HUERTA TOCILDO, Susana, "Los límites del Derecho penal en la prevención de la Violencia doméstica", en Estudios penales en recuerdo del Profesor Ruiz. Antón, Octavio de Toledo y Ubieto/Gurdiel Sierra/Cortés Bechiarelli (coords.), Valencia 2004.

* LAURenZO COPELlo, Patricia, "Violencia de género y Derecho penal de excepción: entre el discurso de la resistencia y el victimismo punitivo", en Estudios penales en Homenaje a Enrique Gimbernat, García Valdés/Cuerda Riezu/Martínez Escamilla/Alcacer Guirao/Valle Mariscal de Gante (coords.), tomo II, Madrid 2008. 
REJ - Revista de Estudios de la Justicia - No 12 - Año 2010

"La violencia de género en la Ley Integral. Valoración político criminal”, en Revista Electrónica de Derecho Penal y Criminología, 2005, http://criminet.ugr.es/recpc, 07-08 (2005), consultada el 25 de Octubre de 2008.

* LÓPEZ GARRIDO, Diego y GARCÍA ARÁN, Mercedes, El Código penal de 1995 y la voluntad del legislador. Comentario al texto y debate parlamentario, Madrid 1996.

* MANJÓN-CABEZA OLMEDA, Araceli, "Violencia de género: discriminación positiva, perspectiva de género y Derecho penal. Algunas cuestiones sobre la competencia de los nuevos juzgados de violencia sobre la mujer", en Tutela penal y Tutela judicial frente a la violencia de género, Madrid 2006.

* MAQUEDA ABREU, María Luisa, "La violencia de género. Entre el concepto jurídico y la realidad social",", en Revista Electrónica de Derecho Penal y Criminología, 2006, http://criminet.ugr.es/recpc, 08-02 (2006), consultada el 25 de Octubre de 2008.

"La violencia habitual en el ámbito familiar: razones de una reforma", en El nuevo Código penal español. Estudios penales en memoria del Profesor José Manuel V alle Muñiz, Quintero Olivares/Morales Prats (direct.), Pamplona, 2001.

"La tortura y otros tratos inhumanos y degradantes", en Anuario de Derecho penal y Ciencias penales, 1986.

* MARÍN DE ESPINOSA CEBALLOS, Elena, La violencia doméstica. Análisis sociológico, dogmático y de derecho comparado, Granada, 2001.

* MARTÍNEZ-BUjÁN PÉREZ, Carlos, "La concepción significativa de la acción de T.S. Vives y sus correspondencias sistemáticas con las concepciones teleológico-funcionales del delito", en Libro Homenaje al Dr. MARÍNo Barbero Santos, Nieto Martín (coord..), Cuenca, 2001.

Prólogo a Núñez Castaño, El delito de malos tratos en el ámbito familiar, Valencia 2002.

* MATA Y MARTIN, Ricardo, "Modificaciones jurídico penales de la LO 1/2004, de medidas de protección integral contra la violencia de género", Revista de Derecho y Proceso Penal, no 15, 2006.

* MENDOZA CALDERÓN, Silvia, "El delito de maltrato ocasional del artículo 153 del Código penal: La influencia del modelo de seguridad ciudadana en el actual Derecho penal", en Estudios sobre la Tutela penal de la Violencia de Género, Núñez Castaño (directora), Valencia 2009.

"Hacia un Derecho penal sin fundamentación material del injusto: la introducción del nuevo art. 153 del Código penal”, en Revista General de Derecho Penal, Mayo 2005, no 3, www.iustel.com, consultado el 19 de Noviembre de 2008.

* MIRAT HERNÁNDEZ, Pilar y ARMENDÁRIZ LEÓN, Carmen, Violencia de género versus violencia doméstica: Consecuencias jurídico penales. Estudio del Titula IV de la Ley Orgánica 1/2004, de 28 de Diciembre, de medidas de protección integral contra la Violencia de Género, Madrid, 2006

* MORILlas CUEVAS, Lorenzo, "Respuestas del Código penal ante la violencia doméstica. Propuestas de reforma”, en Estudios penales sobre la Violencia doméstica, Morillas Cueva (coord..), Madrid 2002.

* MUÑ CONDE, Francisco, Derecho penal, Parte especial, 16 a ed., 2007.

Derecho penal, parte especial, $15^{\mathrm{a}}$ ed., Valencia 2004.

Derecho penal, Parte General, $7^{\mathrm{a}}$ ed., Valencia 2007.

* MUÑOZ SÁNCHEZ, Juan, "El delito de violencia doméstica habitual", en La reforma penal en torno a la violencia doméstica y de género, Boldova Pasamar/Rueda Martín (coords.), Barcelona 2006.

Los delitos contra la integridad moral, Valencia 1999.

* NÚNEZ CASTAÑO, María Elena, "Las transformaciones sociales y el Derecho penal: del estado liberal al Derecho penal de enemigos", en Problemas actuales del Derecho penal y de 
Núñez Castaño - La violencia doméstica en la legislación española...

la Criminología. Estudios penales en memoria de la Profesora Dra. María del Mar Díaz Pita, Muñoz Conde (direct.), Valencia 2008. 2002. El delito de malos tratos en el ámbito familiar, Aspectos fundamentales de la tipicidad, Valencia

* OLMEDO CARDENETE, Miguel, El delito de violencia habitual en el ámbito doméstico: análisis teórico y jurisprudencial, Barcelona, 2001.

* PÉREZ ALONSO, Esteban, "Los nuevos delitos contra la integridad moral en el Código penal de 1995", en Revista de la Facultad de Derecho de la Universidad de Granada, $3^{\mathrm{a}}$ época, nº 2, 1999.

* PÉREZ MACHIO, Ana, "Concepto jurídico de «mobbing», bien jurídico lesionado y su tutela jurídico-penal”, Revista Electrónica de Derecho Penal y Criminología, n 6, 2004, http://criminet.ugr.es/recpc, 06-06 (2004), consultada el 25 de Octubre de 2008.

* QUERALT i JIMÉNEZ, Joan, "La respuesta penal de la Ley Orgánica 1/2004 a la Violencia de Género", en La Ley integral de medidas de protección contra la violencia de género, Cuadernos de Derecho Judicial, XXII, 2005.

"La última respuesta penal a la violencia de género", La Ley, nº 6420, 2006.

* RAMÓN RIBAS, Eduardo, Violencia de género y violencia doméstica, Valencia 2008, págs. 115 y 122 ;

* RODRÍGUEZ MESA, María José, Torturas y otros delitos contra la integridad moral cometidos por funcionarios públicos, Granada, 2000.

* RUBIDO DE LA TORRE, José, Ley de Violencia de Género. Ajuste de constitucionalidad en materia penal, Valencia 2007.

* TAMARIT SUMALLA, Josep, Comentarios al Código penal de 1995, en Quintero Olivares y otros, $2^{\mathrm{a}}$ ed., Elcano 2001.

Comentarios al Código penal de 1995, Pamplona 1996.

* VILLACAMPA ESTIARTE, Carolina, "El maltrato singular cualificado por razón de género. Debate acerca de su constitucionalidad", en Revista Electrónica de Derecho Penal y Criminología, 2007, http://criminet.ugr.es/recpc, 09-12 (2007), consultada el 25 de Octubre de 2008.

* VIVES ANTÓN, Tomás, Fundamentos del sistema penal, Valencia 1996.

* ZAFFARONI, Eugenio, El enemigo en Derecho penal, Dykinson, 2006. 